\title{
Asymmetric Hydroformylation of Vinyl Acetate: Application in the Synthesis of Optically Active Isoxazolines and Imidazoles
}

By

\author{
P.J. Thomas ${ }^{\dagger *}$, Alex T. Axtell ${ }^{\dagger}$, Jerzy Klosin ${ }^{\dagger *}$, Wei Peng ${ }^{\dagger}$, Cynthia L. Rand ${ }^{\dagger}$, Thomas P. Clark \\ Clark R. Landis ${ }^{\ddagger}$ and Khalil A. Abboud ${ }^{\S}$ \\ ${ }^{\dagger}$ Corporate R\&D, The Dow Chemical Company, 1776 Building, Midland, MI 68674 \\ ${ }^{*}$ Department of Chemistry, University of Wisconsin-Madison, 1101 University Avenue, Madison, \\ Wisconsin 53706 \\ ${ }^{\S}$ Department of Chemistry, University of Florida, Gainesville, FL 32611 \\ pjthomas@dow.com,jklosin@dow.com
}

1) Hydroformylation procedures

2) Synthetic procedures

3) X-ray data for $(R)-9$ 


\section{EXPERIMENTAL}

General: Chiral GC analysis was performed on a system comprised of a HP 6890 Gas Chromatograph equipped with a Supelco Beta Dex 225 column $(30 \mathrm{~m})$. Temperature program of $100{ }^{\circ} \mathrm{C}$ for $5 \mathrm{~min}$, then $4{ }^{\circ} \mathrm{C} / \mathrm{min}$ to $160{ }^{\circ} \mathrm{C}$; retention times: $2.40 \mathrm{~min}$ for vinyl acetate, $6.76(S)$ and $8.56(R) \mathrm{min}$ for the enantiomers of the 2-(acetyloxy)-propanal (branched regioisomer), $11.50 \mathrm{~min}$ for 3-(acetyloxy)-propanal (linear regioisomer). NMR spectra were recorded on a Mercury Vx 300 (FT $300 \mathrm{MHz},{ }^{1} \mathrm{H} ; 75 \mathrm{MHz},{ }^{13} \mathrm{C} \mathrm{MHz}$ ) spectrometer. ${ }^{1} \mathrm{H}$ NMR data are reported as follows: chemical sift (multiplicity $(\mathrm{br}=$ broad, $\mathrm{s}=$ singlet, $\mathrm{d}=$ doublet, $\mathrm{t}=$ triplet, $\mathrm{q}=$ quartet, $\mathrm{p}=$ pentet, and $\mathrm{m}=$ multiplet), integration and assignment). Chemical shifts for ${ }^{1} \mathrm{H}$ NMR data are reported in ppm downfield from internal tetramethylsilane (TMS, $\delta$ scale) using residual protons in the deuterated solvents $\left(\mathrm{CDCl}_{3}, 7.25 \mathrm{ppm}\right)$ as references. ${ }^{13} \mathrm{C}$ data were determined with ${ }^{1} \mathrm{H}$ decoupling, and the chemical shifts are reported in ppm vs. tetramethylsilane $\left(\mathrm{CDCl}_{3}, 77 \mathrm{ppm}\right)$.

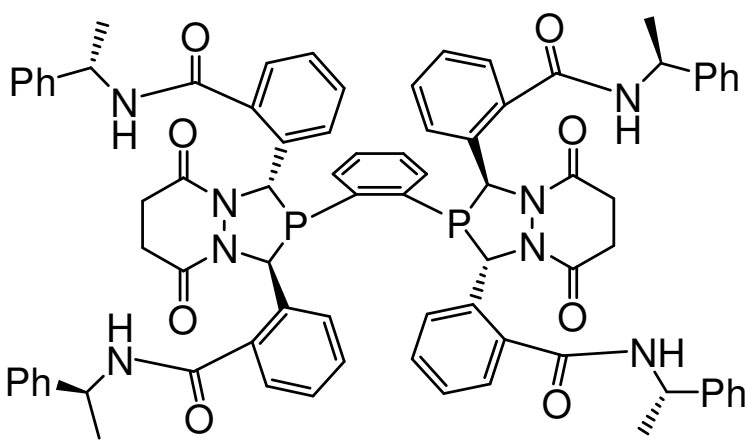

$(S, S)$-Diazaphospholane (1)

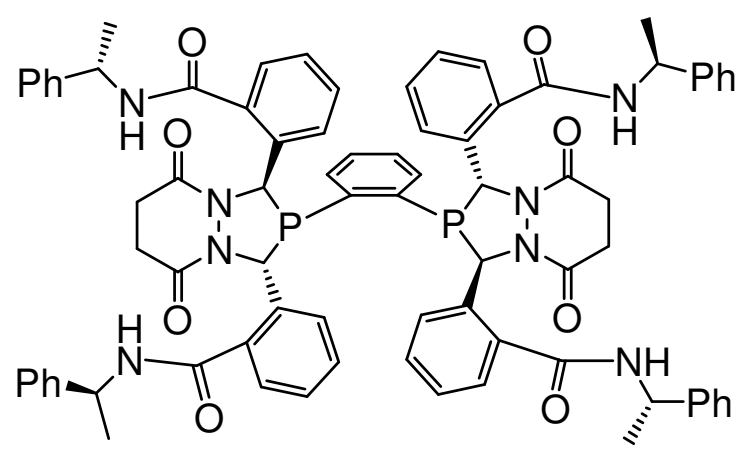

$(R, R)$-Diazaphospholane (3)

\section{$\underline{\text { Hydroformylation in an Endeavor }}{ }^{\circledR}$ reactor}

Hydroformylation reactions were conducted in an Argonaut Endeavor ${ }^{\circledR}$ reactor system housed in an inert atmosphere glove box. The reactor system consisted of eight parallel, mechanically stirred pressure reactors with individual temperature and pressure controls. Solution of $(S, S)$ diazaphospholane (1) $(17 \mu \mathrm{l}$ of $0.03 \mathrm{M}$ solution in THF, $0.51 \mu \mathrm{mol})$ was mixed with $\mathrm{Rh}(\mathrm{CO})_{2}$ (acac) solution $(17 \mu \mathrm{l}$ of $0.025 \mathrm{M}$ in toluene, $0.0 .43 \mu \mathrm{mol})$ in a glass vial in the dry box 
at room temperature. To this mixture was added $4 \mathrm{~mL}$ of vinyl acetate. Upon charging the catalyst solutions, the reactors were pressurized at 50,100, 200, 300 and 400 psi of syngas $\left(\mathrm{CO}: \mathrm{H}_{2} 1: 1\right.$ ) and then heated to $80{ }^{\circ} \mathrm{C}$ while stirring at $800 \mathrm{rpm}$. The runs were stopped after $5 \mathrm{~h}$. by cooling the reactor to $40-50{ }^{\circ} \mathrm{C}$ and subsequent venting the system and purging with nitrogen. Upon opening the reactor a sample of each reaction mixture was taken out and diluted with 1.7 $\mathrm{mL}$ of toluene, and this solution was analyzed by gas chromatography.

\section{$\underline{\text { Hydroformylation in a 300ml Parr reactor }}$}

Synthesis of (S)-2-(acetoxy)-propanal using 2,2',2",2"'-[1,2-phenylenebis[(1S,3S)-tetrahydro-5,8dioxo-1H-[1,2,4]diazaphospholo[1,2-a]pyridazine-2,1,3(3H)-triyl]]tetrakis[N-[(1S)-1phenylethyl]-benzamide) $[S, S)$-diazaphospholane (1)]

A catalyst solution containing $(S, S)$-diazaphospholane (1) $(0.0408 \mathrm{~g}, 0.0311 \mathrm{mmol})$ and $\mathrm{Rh}(\mathrm{acac})(\mathrm{CO})_{2}(0.0040 \mathrm{~g}, 0.0155 \mathrm{mmol})$ in $25.00 \mathrm{~g}$ tetraglyme was transferred into a $300 \mathrm{ml}$ Parr reactor under nitrogen followed by $134.82 \mathrm{~g}(1.567 \mathrm{~mol})$ of vinyl acetate (distilled and degassed). The reactor was purged three times with syngas and then pressurized to 475 psi. The solution was heated to $75{ }^{\circ} \mathrm{C}$ and stirred at $1000 \mathrm{rpm}$. The reaction was run for 23 hours. GC analysis of the reaction solution showed $98.9 \%$ conversion $(99962$ TON) of vinyl acetate, $96.8 \%$ ee and 46.9/1 b/l ratio. The reaction solution was collected in a 500ml Schlenk flask, which was then attached to a vacuum distillation apparatus under nitrogen. The solution was stirred at ambient temperature while the pressure was reduced to $8.5 \mathrm{mmHg}$ using a liquid nitrogen trap to collect the volatiles. The flask was then heated to a target temperature of $65{ }^{\circ} \mathrm{C}$ using a water bath. The receiving flask was cooled with liquid nitrogen when the vapor temperature reached 40 ${ }^{\circ} \mathrm{C}$. The product was collected with the vapor temperature between 40 and $45^{\circ} \mathrm{C}$ and the pressure between 9 and $7 \mathrm{mmHg}$. When the vapor temperature dropped below $35^{\circ} \mathrm{C} / 8.5 \mathrm{mmHg}$, the receiving flask was replaced and the bath temperature was raised to $85{ }^{\circ} \mathrm{C}$ and the pressure again reduced to $8.5 \mathrm{mmHg}$ to purge the remaining product and higher boiling by-products. Yield: $155.0 \mathrm{~g}(85.2 \%)$. GC analysis of the isolated product showed $96.8 \%$ ee and 139/1 b/l ratio. The low isolated yield was due to stopping the distillation early to obtain a higher b/l ratio. 
Synthesis of $(R)$-2-(acetoxy)-propanal using $\left(2,2^{\prime}, 2^{\prime \prime}, 2^{2 "}-[1,2\right.$-phenylenebis[$[(1 R, 3 R)$-tetrahydro5,8-dioxo-1H-[1,2,4]diazaphospholo[1,2-a]pyridazine-2,1,3(3H)-triyl]]tetrakis[N-[(1S)-1phenylethyl]-benzamide $[(R, R)$-diazaphospholane $(3)]$

A catalyst solution was prepared in a dry box by dissolving $(R, R)$-diazaphospholane $(3)$ $(0.4886 \mathrm{~g}, 0.3726 \mathrm{mmol})$ and $\mathrm{Rh}(\mathrm{acac})(\mathrm{CO})_{2}(0.0544 \mathrm{~g}, 0.2109 \mathrm{mmol})$ in $19.21 \mathrm{~g}$ tetraglyme. The catalyst was transferred into a $300 \mathrm{ml}$ Parr reactor under nitrogen, purged three times with syngas and then pressurized to $475 \mathrm{psi}$. The solution was heated to $50^{\circ} \mathrm{C}$ and stirred at $1000 \mathrm{rpm}$. Vinyl acetate (36.63 g, $425.48 \mathrm{mmol}$, degassed) was transferred into a substrate cylinder attached to a valve on the reactor. The cylinder was purged with syngas three times and pressurized to 500 psi. After the reactor was stirred for 15 minutes at $50{ }^{\circ} \mathrm{C}$, the syngas in the reactor was vented to about 400 psi and the valve that connected the substrate cylinder to the reactor was opened to pressurize vinyl acetate into the reactor. After 3.5 hours, GC analysis determined that the conversion of vinyl acetate was $98.6 \%$. A second addition of vinyl acetate (113.9 g, 1,323 mmol) was carried out and the reaction was continued overnight. GC analysis of the reaction solution showed $99.9 \%$ vinyl acetate conversion, $93.8 \%$ ee and 28.7/1 b/1 ratio. Product was isolated following distillation procedure described above. The first fraction collected $181.5 \mathrm{~g}(92.8 \%$ based on a total of $150.5 \mathrm{~g}$ vinyl acetate used minus losses of about $5.5 \mathrm{~g}$ from sampling) product with $93.8 \%$ ee and 102/1 b/l ratio. The second fraction collected $7.0 \mathrm{~g}$, which contained more linear aldehyde 3-acetoxypropanal $(b / 1=26)$ and unidentified by-products.

Preparation of aldoxime $(S)$-6. To a stirred solution of the $(S)$-2-(acetyloxy)-propanal (5) (3.0 g, 26 $\mathrm{mmol})$ and hydroxylamine hydrochloride $(1.97 \mathrm{~g}, 28 \mathrm{mmol})$ in $50 \mathrm{~mL}$ of THF/water $(3: 2)$ at $0{ }^{\circ} \mathrm{C}$ was added a solution of pyridine $(2.3 \mathrm{~mL}, 28 \mathrm{mmol})$ in $5 \mathrm{~mL}$ of THF over a period of 20 minutes. The mixture was slowly warmed to room temperature and stirred for 6 more hours. THF was removed by rotary evaporation and the mixture was extracted with ether. The ether layer was washed with water, $10 \%$ solution of citric acid and brine. Removal of the solvent after drying over anhydrous magnesium sulfate gave $3.4 \mathrm{~g}(90 \%)$ of mixture (syn/anti) of aldoxime $(S)-6$ as a viscous oil which solidified in a freezer: ${ }^{1} \mathrm{H}$ NMR $\left(\mathrm{CDCl}_{3}\right) \delta 9.06$ (br. s, $\left.1 \mathrm{H}\right), 7.41$, 6.72 ( two sets of doublets, $J=5.22 \mathrm{~Hz}, 1 \mathrm{H}$ ), 5.90, 5.46 (two sets of multiplets, $1 \mathrm{H}$ ), 2.08 (s, 3H) 
and 1.41( $\mathrm{d}, J=6.6 \mathrm{~Hz}) ;{ }^{13} \mathrm{C}\left\{{ }^{1} \mathrm{H}\right\} \mathrm{NMR}\left(\mathrm{CDCl}_{3}\right) \quad \delta 170.39,170.37,151.75,149.70,67.65$, 65.05, 20.86, 20.83, 17.81 and 16.66. MS: TMS derivative $\left(\mathrm{C}_{8} \mathrm{H}_{17} \mathrm{O}_{3} \mathrm{NSi}\right) \mathrm{m} / \mathrm{e} 203.1$.

Preparation of $(S)$-1-amino-2-propanol (S-7). To a stirred suspension of $2.0 \mathrm{~g}(53 \mathrm{mmol})$ of lithium aluminum hydride in $100 \mathrm{~mL}$ of dry ether under nitrogen atmosphere at $0-5{ }^{\circ} \mathrm{C}$, a solution of $2.0 \mathrm{~g}(15 \mathrm{mmol})$ of $(S)-6$ in $20 \mathrm{ml}$ of dry ether was added slowly over a 30 minute period. The mixture was warmed to room temperature and stirred for 18 hours. The mixture was then diluted with $50 \mathrm{~mL}$ of ether, and a saturated sodium sulfate solution was added very slowly while stirring until the formation a granular white precipitate. The solution was filtered and the solid was washed with ether. The combined ether solution was dried over anhydrous sodium sulfate. Removal of the solvent gave $0.8 \mathrm{~g}(70 \%)$ of 7 as an oil. The ${ }^{1} \mathrm{H}$ NMR spectrum of this product was in full agreement with that of an authentic sample. ${ }^{1} \mathrm{H}$ NMR $\left(\mathrm{CDCl}_{3}\right) \delta$ 3.65-2.55 (m, 1H), 3.80-2.40 (br s, 3H), $2.65(\mathrm{dd}, J=2.65 \mathrm{~Hz}$ and $12.7 \mathrm{~Hz}, 1 \mathrm{H}), 2.44(\mathrm{dd}, J=8.1 \mathrm{~Hz}$ and $12.7 \mathrm{~Hz})$ and $1.06(\mathrm{~d}, J=6.3 \mathrm{~Hz})$.

Preparation of hydroxamoyl chloride $(S)-9$. To a stirred solution of $1.31 \mathrm{~g}(10.0 \mathrm{mmol})$ of $(S)-6$ in $25 \mathrm{~mL}$ of DMF at $25{ }^{\circ} \mathrm{C}$ was added about one-fifth of $1.33 \mathrm{~g}(10.0 \mathrm{mmol})$ of solid $\mathrm{N}$ chlorosuccinimide. The mixture was stirred for 15 minutes and then introduced a small amount of $\mathrm{HCl}$ gas to the DMF solution $(\mathrm{HCl}$ gas was taken from the head space of concentrated $\mathrm{HCl}$ reagent bottle with a syringe). The remainder of $\mathrm{N}$-chlorosuccinimide was added slowly keeping the temperature of the reaction below $40{ }^{\circ} \mathrm{C}$. The mixture was stirred for an additional four hours and poured into ice water. The mixture was extracted with ether, washed with water and brine and dried over anhydrous magnesium sulfate. Removal of the solvent gave $1.42 \mathrm{~g}(86 \%)$ of 8 as viscous oil which solidified in a freezer. ${ }^{1} \mathrm{H}$ NMR $\left(\mathrm{CDCl}_{3}\right) \delta 9.21(\mathrm{~s}, 1 \mathrm{H}), 5.62(\mathrm{q}, J=$ $6.6 \mathrm{~Hz}, 1 \mathrm{H}), 2.12(\mathrm{~s}, 3 \mathrm{H}), 1.50(\mathrm{~d}, J=6.6 \mathrm{~Hz}, 3 \mathrm{H}) .{ }^{13} \mathrm{C}\left\{{ }^{1} \mathrm{H}\right\} \mathrm{NMR}\left(\mathrm{CDCl}_{3}\right) \delta$ 170.17, 139.77, 70.46, 20.95, 17.94 .

Preparation of isoxazoline 10. To a stirred mixture of $1.04 \mathrm{~g}(10.0 \mathrm{mmol})$ of styrene, $23 \mathrm{~mL}$ (15 $\mathrm{mmol}$ ) of $5 \%$ solution of sodium hypochlorite in water (household bleach), $0.10 \mathrm{~g}$ (1.0 mmol) of triethylamine and $20 \mathrm{~mL}$ of $\mathrm{CH}_{2} \mathrm{Cl}_{2}$ at $0{ }^{\circ} \mathrm{C}, 1.31 \mathrm{~g}(10.0 \mathrm{mmol})$ of $(S)-6$ in $10 \mathrm{~mL}$ of $\mathrm{CH}_{2} \mathrm{Cl}_{2}$ was added slowly over a period of 30 minutes. The mixture was stirred at $0{ }^{\circ} \mathrm{C}$ for 3 more hours. 
The organic layer was separated, and the aqueous layer was extracted with $\mathrm{CH}_{2} \mathrm{Cl}_{2}$. The combined organic layers was washed with water and brine, and dried over anhydrous magnesium sulfate. Removal of the solvent followed by purification by flash chromatography using $10 \%$ ethyl acetate in hexanes gave $1.48 \mathrm{~g}$ of $\mathbf{1 0}(64 \%)$ as a diastereomeric mixture $\left(\mathrm{R}_{\mathrm{f}}=0.19\right) .{ }^{1} \mathrm{H}$ $\operatorname{NMR}\left(\mathrm{CDCl}_{3}\right) \delta 7.33(\mathrm{~m}, 5 \mathrm{H}), 5.72-5.55(\mathrm{~m}, 2 \mathrm{H}), 3.49-3.33(\mathrm{~m}, 1 \mathrm{H}), 3.02-2.84(\mathrm{~m}, 1 \mathrm{H}), 2.07(\mathrm{~s}$, $3 \mathrm{H}$ ), 1.51 (two overlapping doublets, $J=6.3 \mathrm{~Hz}, 3 \mathrm{H}) .{ }^{13} \mathrm{C}\left\{{ }^{1} \mathrm{H}\right\} \mathrm{NMR}\left(\mathrm{CDCl}_{3}\right) \delta 169.61,157.53$, 140.38, 128.54, 128.53, 128.04, 128.02, 125.59, 125.54, 82.17, 65.89, 42.46, 42.37, 20.94, 20.92, 18.02. MS: $\mathrm{m} / \mathrm{e} 256.0936\left(\mathrm{M}+\mathrm{Na}\right.$, calculated for $\left.\mathrm{C}_{13} \mathrm{H}_{15} \mathrm{NO}_{3}+\mathrm{Na}=256.0950\right)$

Preparation of isoxazoline 11. Reaction of $1.34 \mathrm{~g}(10.0 \mathrm{mmol})$ of 4-methoxystyrene, $1.31 \mathrm{~g}$ (10.0 $\mathrm{mmol})$ of $(S)-6,23 \mathrm{~mL}$ of $5 \%$ sodium hypochlorite solution $(15 \mathrm{mmol})$ and $0.10 \mathrm{~g}(1.0 \mathrm{mmol})$ of triethylamine in $\mathrm{CH}_{2} \mathrm{Cl}_{2}$ as desribed for $\mathbf{1 0}$ followed by purification by flash chromatography using $10 \%$ ethyl acetate in hexanes gave $1.7 \mathrm{~g}(65 \%)$ of $\mathbf{1 1}$ as a diastereomeric mixture $\left(\mathrm{R}_{\mathrm{f}}\right.$ $=0.10) .{ }^{1} \mathrm{H} \mathrm{NMR}\left(\mathrm{CDCl}_{3}\right) \delta$ 7.24-7.20 (m, 2H), 6.87-6.84 (m, 2H), 5.69-5.67 (m, 1H), 5.55-5.48 $(\mathrm{m}, 1 \mathrm{H}), 3.76(\mathrm{~s}, 3 \mathrm{H}), 3.37-3.26(\mathrm{~m}, 1 \mathrm{H}), 2.99-2.91(\mathrm{~m}, 1 \mathrm{H}), 2.05(\mathrm{~s}, 3 \mathrm{H}), 1.50$ (two overlapping doublets, 3H). ${ }^{13} \mathrm{C}\left\{{ }^{1} \mathrm{H}\right\}$ NMR $\left(\mathrm{CDCl}_{3}\right) \delta 169.64,159.34,157.63,132.28,127.08,127.06$, 113.94, 113.91, 82.09, 65.98, 65.96, 55.23, 42.16, 42.10, 20.95, 20.94, 18.02. MS: m/e 286.1058 $\left(\mathrm{M}+\mathrm{Na}\right.$, calculated for $\left.\mathrm{C}_{14} \mathrm{H}_{17} \mathrm{NO}_{4}+\mathrm{Na}=286.1055\right)$.

Preparation of isoxazoline 12. To a stirred solution of $0.40 \mathrm{~g}(3.8 \mathrm{mmol})$ of 4-vinylpyridine and $0.60 \mathrm{~mL}$ (4.3 mmol) of triethylamine in $10 \mathrm{~mL}$ of $\mathrm{CH}_{2} \mathrm{Cl}_{2}$ at room temperature, a solution of 0.63 $\mathrm{g}(3.8 \mathrm{mmol})$ of $(S)-9$ in $10 \mathrm{~mL}$ of $\mathrm{CH}_{2} \mathrm{Cl}_{2}$ was added slowly over a period of 30 minutes. The mixture was stirred for 4 more hours. The mixture was diluted with $50 \mathrm{~mL}$ of $\mathrm{CH}_{2} \mathrm{Cl}_{2}$ and washed with water and brine. Drying over anhydrous magnesium sulfate followed by removal of solvent and purification by flash chromatography using $2.5 \%$ methanol in chloroform gave 0.71 $\mathrm{g}(80 \%)$ of 12 as an oil with slight impurity $\left(\mathrm{R}_{\mathrm{f}}=0.41\right) .{ }^{1} \mathrm{H} \mathrm{NMR}\left(\mathrm{CDCl}_{3}\right) \delta 8.60(\mathrm{~m}, 2 \mathrm{H}), 7.25$ (m, 2H), 5.78-5.56 (m, 2H), 3.58-3.45 (m, 1H), 2.99-2.85 (m, 1H), 2.079, 2.077 (two s, 3H), 1.51 (two overlapping doublets, 3H). ${ }^{13} \mathrm{C}\left\{{ }^{1} \mathrm{H}\right\}$ NMR $\left(\mathrm{CDCl}_{3}\right) \delta$ 169.38, 169.37, 157.40, 157.35, 149.90, 149.88, 149.25, 149.21, 120.04, 120.01, 80.10, 80.07, 65.53, 65.50, 42.24, 42.21, 20.75, 20.73, 17.90, 17.87.. S: m/e 235.1093 $\left(\mathrm{M}+\mathrm{H}\right.$, calculated for $\left.\mathrm{C}_{12} \mathrm{H}_{14} \mathrm{~N}_{2} \mathrm{O}_{3}+\mathrm{H}=235.1083\right)$. 
Preparation of aldoxime $(R)-\mathbf{6}$. Reaction of $15.0 \mathrm{~g}(0.13 \mathrm{~mol})$ of $(R)-5,9.87 \mathrm{~g}(0.14 \mathrm{~mol})$ of hydroxylamine hydrochloride and $11.4 \mathrm{~mL}(0.14 \mathrm{~mol})$ of pyridine in $100 \mathrm{~mL}$ of THF/water (3:2) as described for $(S)$-6 gave $15.0 \mathrm{~g}(89 \%)$ of $(R)$-6. The NMR spectral data of $(R)$-6 were identical with that of $(S)-6$.

Preparation of hydroxamoyl chloride $(R)-\mathbf{9}$. By following the procedure described for $(S)-\mathbf{9}, 11.0$ $\mathrm{g}$ of $(R)-9(85 \%)$ was prepared from $10.0 \mathrm{~g}$ of $(R)-6$ and $10.5 \mathrm{~g}$ of $\mathrm{N}$-chlorosuccinimide. The NMR data of $(R)-\mathbf{9}$ were identical with that of $(S)-9$.

Preparation of allylbenzylamine. ${ }^{1}$ A mixture of $8.0 \mathrm{~g}(0.2 \mathrm{~mol})$ of sodium hydroxide in $60 \mathrm{~mL}$ of water, $21.4 \mathrm{~g}(0.199 \mathrm{~mol})$ of benzylamine and $15.2 \mathrm{~g}(0.199 \mathrm{~mol})$ of allyl chloride was stirred under reflux for 15 hours. The mixture was cooled and extracted with methylene chloride. The organic layer was dried over anhydrous magnesium sulfate. The solvent was removed by distillation, and the resulting liquid, which was a mixture of allylbenzylamine and diallylbenzylamine, was distilled under reduced pressure (aspirator pressure). The fraction boiling at $95-100{ }^{\circ} \mathrm{C}$ was collected to obtain $8.0 \mathrm{~g}$ of allylbenzylamine (28\% yield). ${ }^{1} \mathrm{H}$ NMR $\left(\mathrm{CDCl}_{3}\right) \delta 7.31(\mathrm{~m}, 5 \mathrm{H}), 5.94-5.88(\mathrm{~m}, 1 \mathrm{H}), 5.21-5.09(\mathrm{~m}, 2 \mathrm{H}), 3.77(\mathrm{~s}, 2 \mathrm{H})$ and 3.29-3.26 (m, $2 \mathrm{H})$.

Preparation of $\mathrm{N}-\mathrm{O}$-pentafluorobenzoyl amidoxime $(R)-\mathbf{1 4}$. A solution of $1.68 \mathrm{~g}(9.97 \mathrm{mmol})$ of $(R)-9$ and $2.0 \mathrm{~g}(13.8 \mathrm{mmol})$ of allylbenzylamine in $10 \mathrm{~mL}$ of DMF was stirred at room temperature for 6 hours. This solution was poured into $75 \mathrm{~mL}$ of water and extracted with ether. The ether solution was washed with water, brine and dried over anhydrous magnesium sulfate. Removal of the solvent followed by purification by flash chromatography using $20 \%$ ethyl acetate in hexanes gave $1.8 \mathrm{~g}(65 \%)$ of $(R)-\mathbf{1 3}$ as a mixture of $\mathrm{E}$ and $\mathrm{Z}$ isomers. This product was used for the next step.

To a stirred solution of $1.3 \mathrm{~g}(4.7 \mathrm{mmol})$ of $(R)-13$ and $0.91 \mathrm{~mL}(6.5 \mathrm{mmol})$ of triethylamine in $10 \mathrm{~mL}$ of $\mathrm{CH}_{2} \mathrm{Cl}_{2}$ at $0{ }^{\circ} \mathrm{C}$ under nitrogen atmosphere, pentafluorobenzoyl chloride $(1.4 \mathrm{~g}, 6.1$ $\mathrm{mmol}$ ) in $5 \mathrm{~mL}$ of methylene chloride was added over a period of 20 minutes. The mixture was stirred at $0{ }^{\circ} \mathrm{C}$ for 4 hours. This was poured into water and extracted with $\mathrm{CH}_{2} \mathrm{Cl}_{2}$. The organic

\footnotetext{
${ }^{1}$ Carpino, L. A.; Santilli, A.A.; Murray, R. W., J. Am. Chem. Soc. 1960, 82, 2728.
} 
layer was washed with water and brine. The solution was dried over anhydrous magnesium sulfate. Removal of the solvent followed by purification by flash chromatography using $20 \%$ ethyl acetate in hexanes gave $2.05 \mathrm{~g}(92 \%)$ of $(R)-\mathbf{1 4}$ as a mixture of isomers. A small portion was further subjected to flash chromatography using $10 \%$ ethyl acetate in hexanes to obtain the major isomer in pure form as an oil $\left(\mathrm{R}_{\mathrm{f}}=0.31\right) .{ }^{1} \mathrm{H}$ NMR $\left(\mathrm{CDCl}_{3}\right) \delta 7.38-7.20(\mathrm{~m}, 5 \mathrm{H}), 6.06(\mathrm{q}, J$ $=7.08 \mathrm{~Hz}, 1 \mathrm{H}), 5.87(\mathrm{~m}, 1 \mathrm{H}), 5.19(\mathrm{~m}, 2 \mathrm{H}), 4.72(\mathrm{~d}, J=15 \mathrm{~Hz}, 1 \mathrm{H}), 4.50(\mathrm{~d}, J=15 \mathrm{~Hz}, 1 \mathrm{H})$, $4.14(\mathrm{~m}, 1 \mathrm{H}), 3.81(\mathrm{~m}, 1 \mathrm{H}), 1.92(\mathrm{~s}, 3 \mathrm{H})$ and $1.57(\mathrm{~d}, J=7.08,3 \mathrm{H}) . \mathrm{MS}: \mathrm{m} / \mathrm{e} 493.1155(\mathrm{M}+\mathrm{Na}$, calculated for $\mathrm{C}_{22} \mathrm{H}_{19} \mathrm{~F}_{5} \mathrm{~N}_{2} \mathrm{O}_{4}+\mathrm{Na}=493.1163$ ).

Preparation of imidazole $(R)$-15. A solution of $1.30 \mathrm{~g}(2.77 \mathrm{mmol})$ of $(R)-\mathbf{1 4}, 2.05 \mathrm{~mL}(14.7$ mmol) of triethylamine and $0.10 \mathrm{~g}(0.09 \mathrm{mmol})$ of $\mathrm{Pd}\left(\mathrm{PPh}_{3}\right)_{4}$ in $15 \mathrm{~mL}$ of $\mathrm{DMF}$ under the atmosphere of nitrogen was heated to $85^{\circ} \mathrm{C}$ for 6 hours. The mixture was cooled and then poured into $100 \mathrm{~mL}$ of water and extracted with ether. The organic layer was washed with water and brine. The solution was then dried over anhydrous magnesium sulfate. Removal of the solvent followed by purification by flash chromatography using $60 \%$ ethyl acetate in hexanes gave $0.45 \mathrm{~g}(63 \%)$ of $(R)-\mathbf{1 5}\left(\mathrm{R}_{\mathrm{f}}=0.38\right) .{ }^{1} \mathrm{H}$ NMR $\left(\mathrm{CDCl}_{3}\right) \delta$ 7.32-7.27 (m, 3H), $7.04(\mathrm{~m}, 2 \mathrm{H})$, $6.61(\mathrm{~s}, 1 \mathrm{H}), 5.93(\mathrm{q}, J=6.6 \mathrm{~Hz}, 1 \mathrm{H}), 5.19(\mathrm{~d}, J=16.1 \mathrm{~Hz}, 1 \mathrm{H}), 5.05(\mathrm{~d}, J=16.1 \mathrm{~Hz}, 1 \mathrm{H}), 2.40$ $(\mathrm{s}, 3 \mathrm{H}), 1.83(\mathrm{~s}, 3 \mathrm{H}), 1.61(\mathrm{~d}, J=6.6 \mathrm{~Hz}, 3 \mathrm{H}) .{ }^{13} \mathrm{C}\left\{{ }^{1} \mathrm{H}\right\} \mathrm{NMR}\left(\mathrm{CDCl}_{3}\right) \quad \delta$ 170.14, 145.05, $136.92,136.59,128.62,127.59,126.24,117.54,63.24,48.96,20.55,18.55,13.46$. MS: m/e 259.1449 (M+H, calculated for $\left.\mathrm{C}_{15} \mathrm{H}_{18} \mathrm{~N}_{2} \mathrm{O}_{2}+\mathrm{H}=259.1447\right)$.

Preparation of $\mathrm{N}$-O-pentafluorobenzoyl amidoxime $(S)$-14 By following the procedure described for $(R)-14$, first the reaction of $1.68 \mathrm{~g}(9.97 \mathrm{mmol})$ of $(S)-9$ and $2.0 \mathrm{~g}(13.8 \mathrm{mmol})$ of allylbenzylamine in DMF gave $1.20 \mathrm{~g}(43 \%)$ of $(S)-\mathbf{1 3}$ as isomeric mixture. Conversion of 1.10 $\mathrm{g}(3.98 \mathrm{mmol})$ of $(S)-13 \mathrm{using} 1.10 \mathrm{~g}(4.78 \mathrm{mmol})$ of pentafluorobenzoyl chloride afforded $1.2 \mathrm{~g}$ $(64 \%)$ of $(S)-14$. The NMR spectral data of the major ester isolated from this mixture were identical with that of $(R)-\mathbf{1 4}$.

Preparation of imidazole $(S)$-15. Reaction of $500 \mathrm{mg}(1.06 \mathrm{mmol})$ of 18 with $40 \mathrm{mg}(0.035$ $\mathrm{mmol})$ of $\mathrm{Pd}\left(\mathrm{PPh}_{3}\right)_{4}$ and $0.8 \mathrm{~mL}(5.75 \mathrm{mmol})$ of triethylamine in DMF followed by purification as described for $(R)-\mathbf{1 5}$ yielded $0.15(54 \%)$ of $(S)$-15. The NMR spectral data were identical with that of $(R)-15$. MS: m/e 259.1432 $\left(\mathrm{M}+\mathrm{H}\right.$, calculated for $\left.\mathrm{C}_{15} \mathrm{H}_{18} \mathrm{~N}_{2} \mathrm{O}_{2}+\mathrm{H}=259.1447\right)$. 
Chiral HPLC chromatograms of imidazole derivatives derived from $(R)$ - and (S)-2acetoxypropanaldehyde. Representative chiral HPLC chromatograms $(4.6$ x 250mm Chirapak AD column), eluent: $5 \%$ ethanol in hexane.
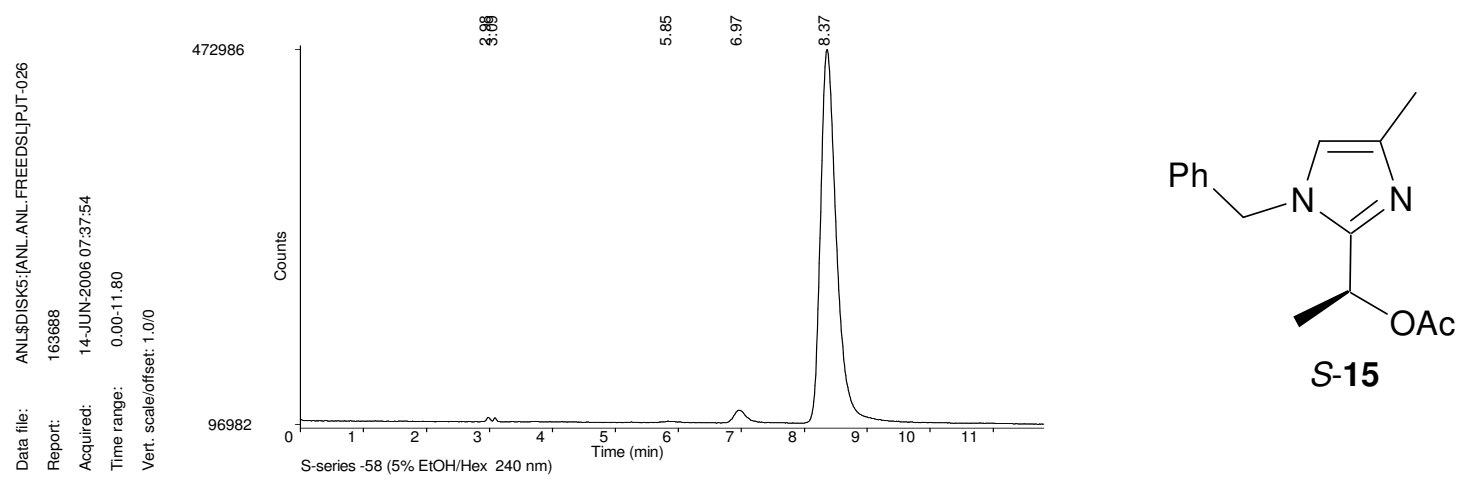

Retention times in minutes: 6.97 and 8.37 min., $94.9 \%$ ee

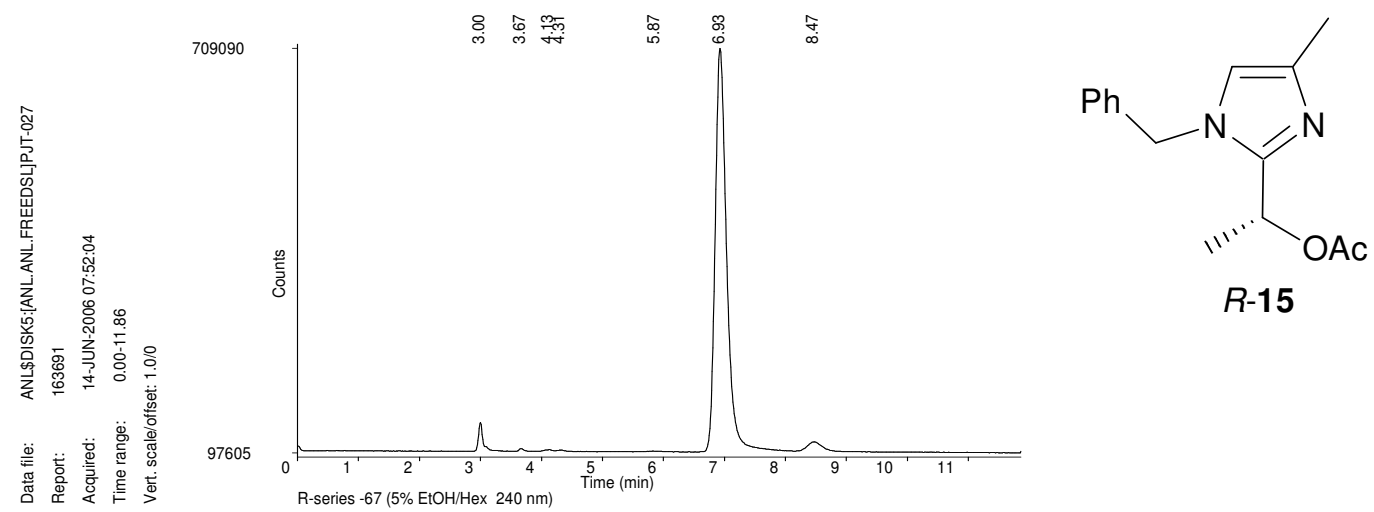

Retention times in minutes: 6.93 and 8.47 min., ee: 94.2 
Figure $1 .{ }^{1} \mathrm{H}$ and ${ }^{13} \mathrm{C}\left\{{ }^{1} \mathrm{H}\right\}$ spectra of $(R)-9$.
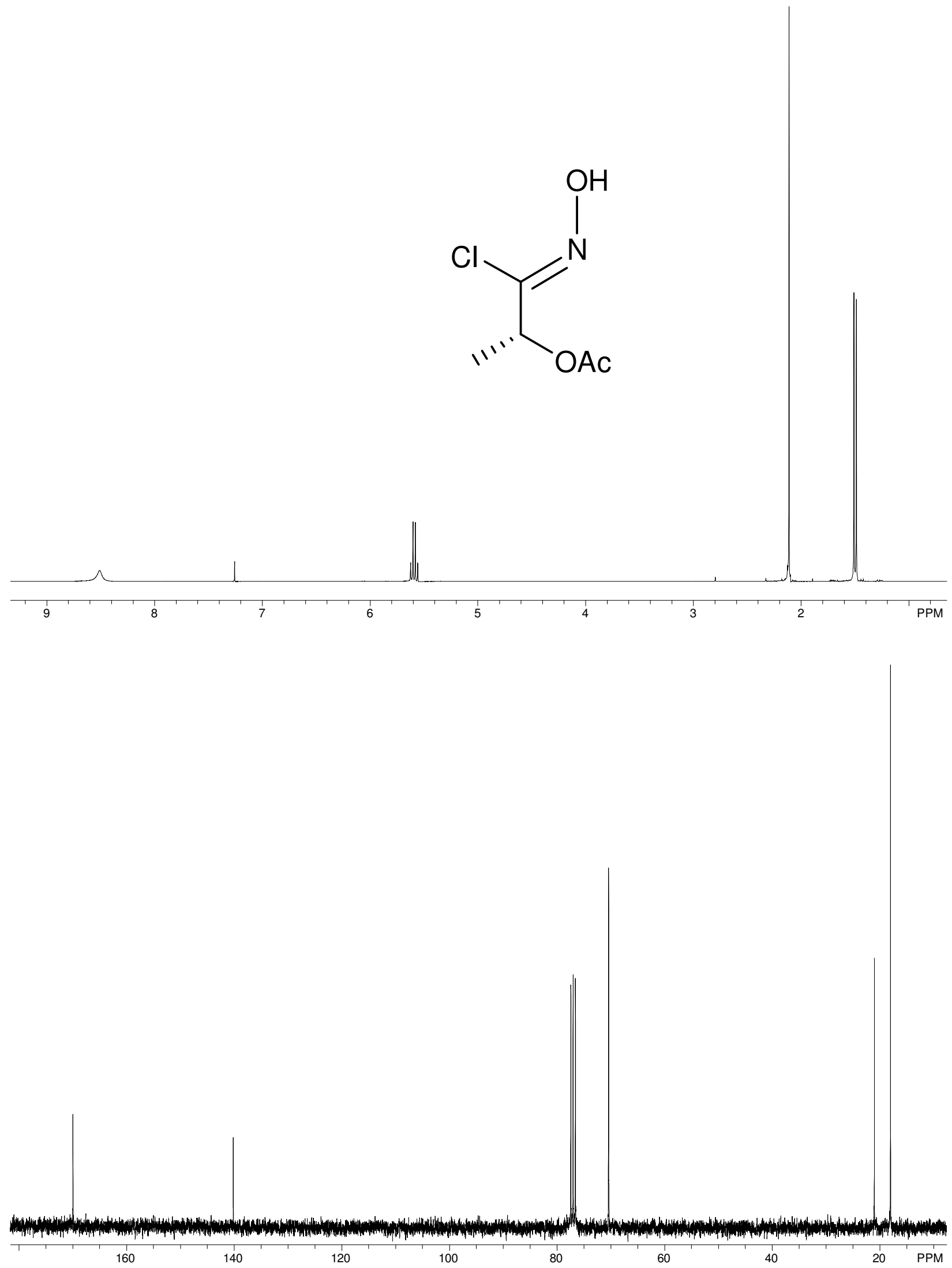
Figure 2. ${ }^{1} \mathrm{H}$ and ${ }^{13} \mathrm{C}\left\{{ }^{1} \mathrm{H}\right\}$ spectra of $\mathbf{1 0}$.
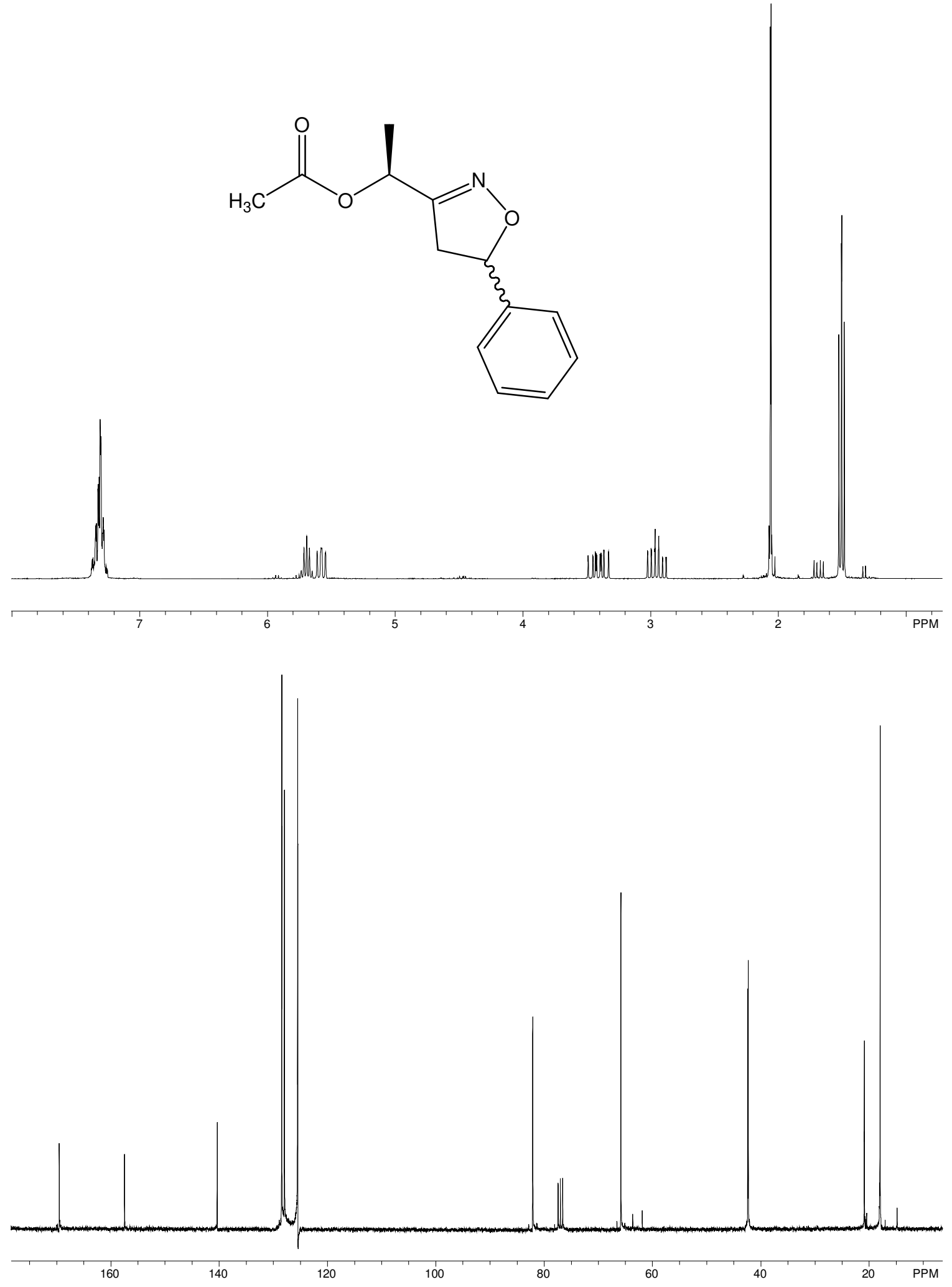
Figure 3. APT spectrum of $\mathbf{1 0}$.

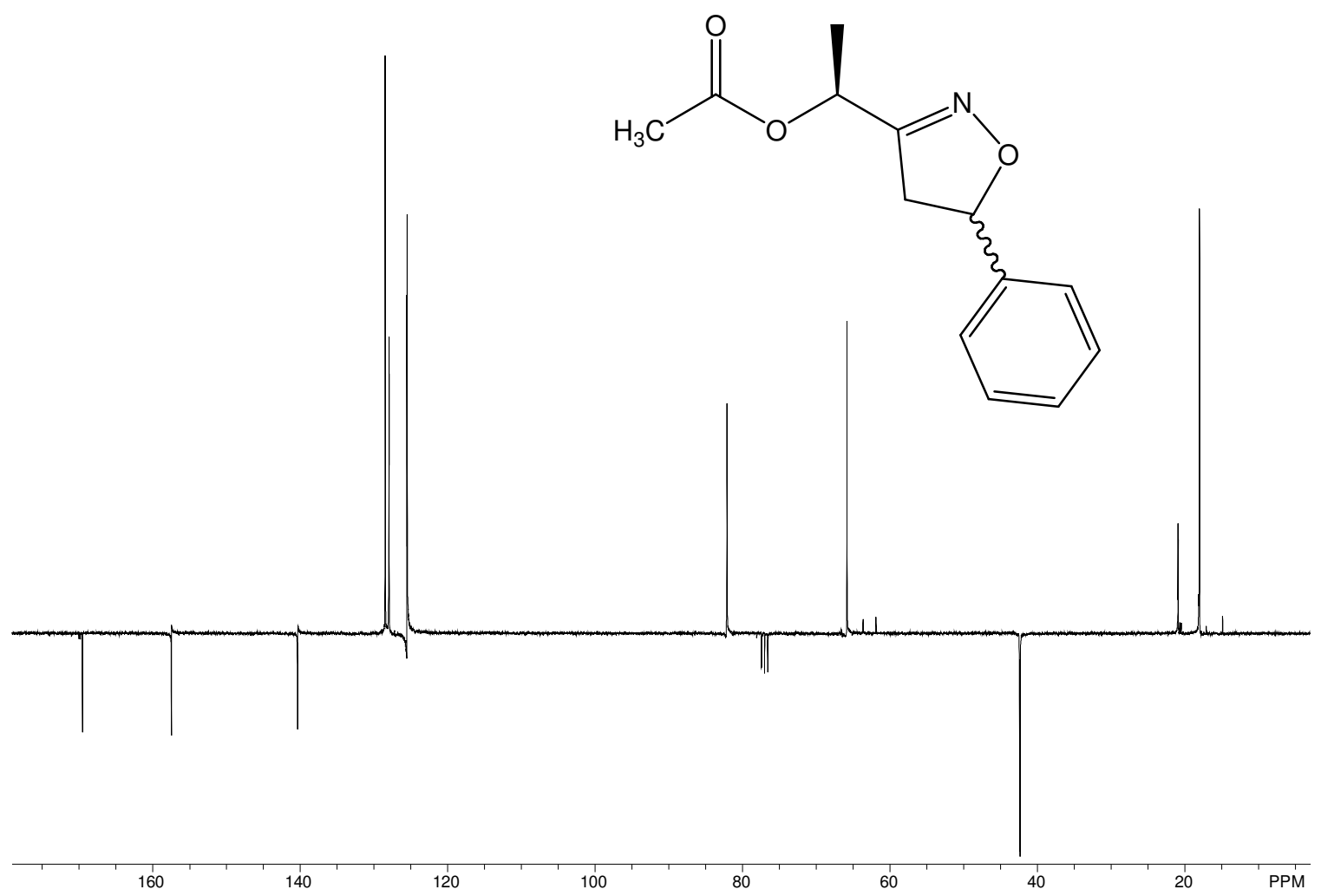


Figure 4. COSY spectrum of $\mathbf{1 0 .}$

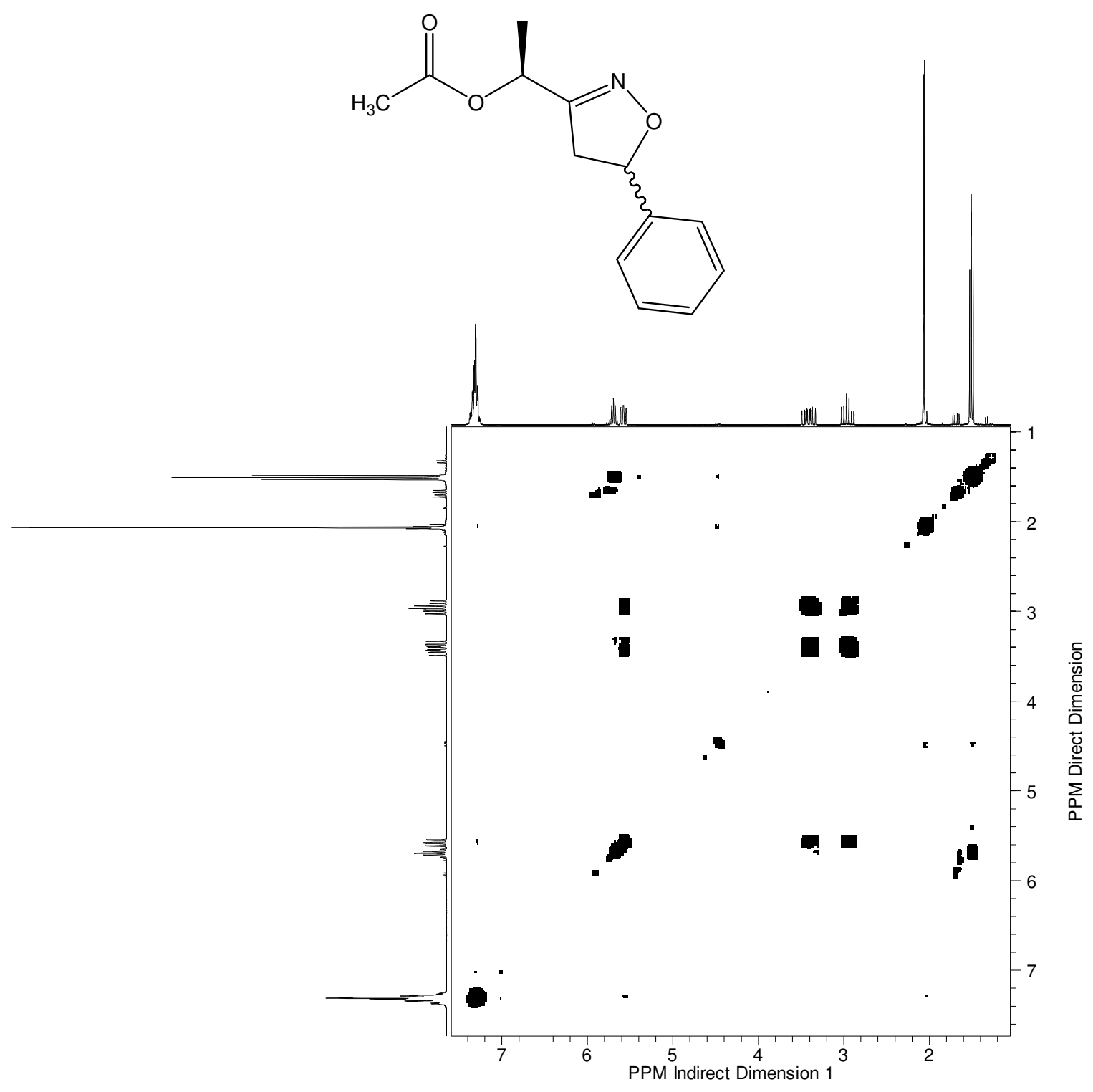


Figure 5. HSQC spectrum of $\mathbf{1 0 .}$

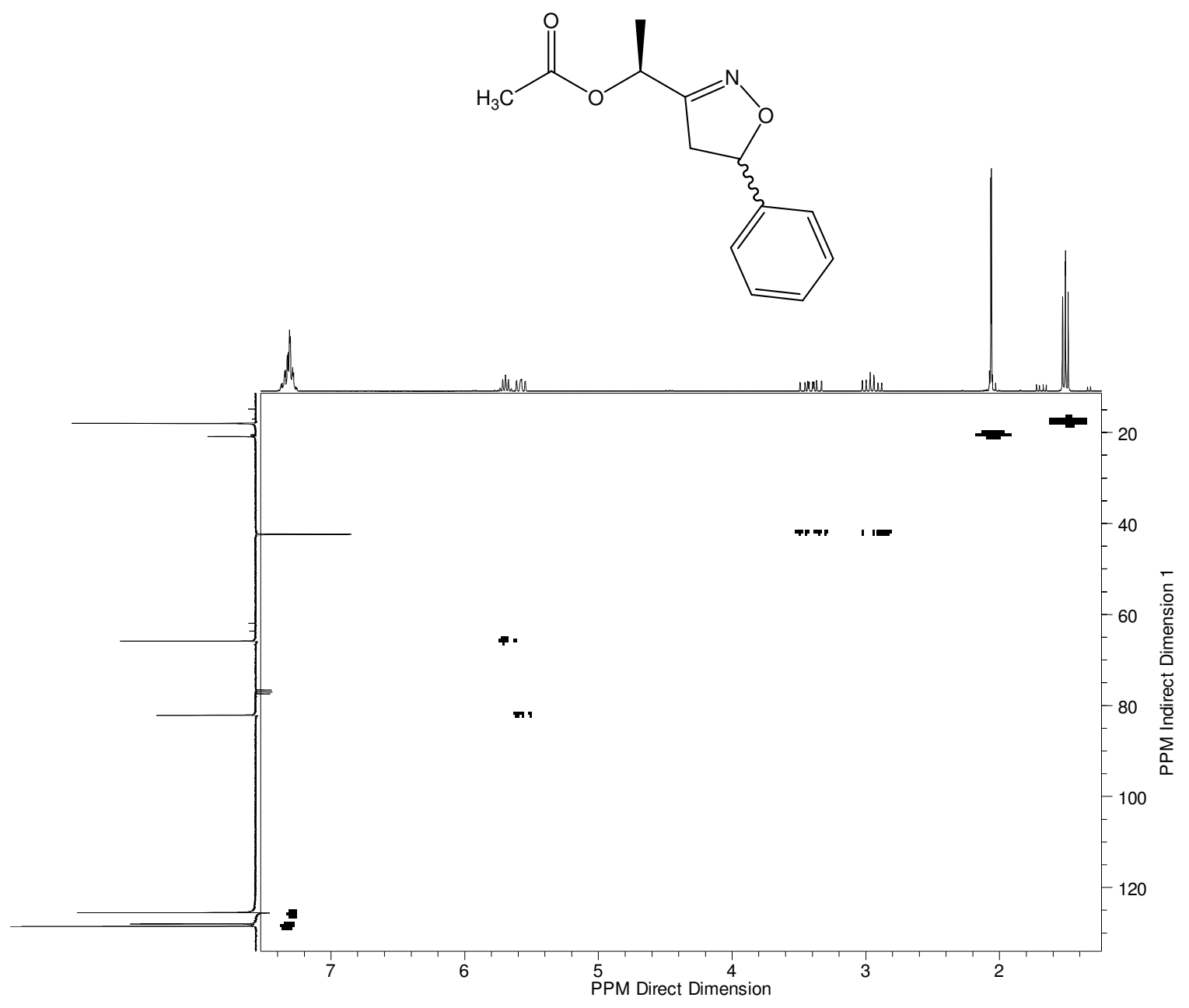


Figure 6. ${ }^{1} \mathrm{H}$ and ${ }^{13} \mathrm{C}\left\{{ }^{1} \mathrm{H}\right\}$ spectra of $\mathbf{1 1}$.

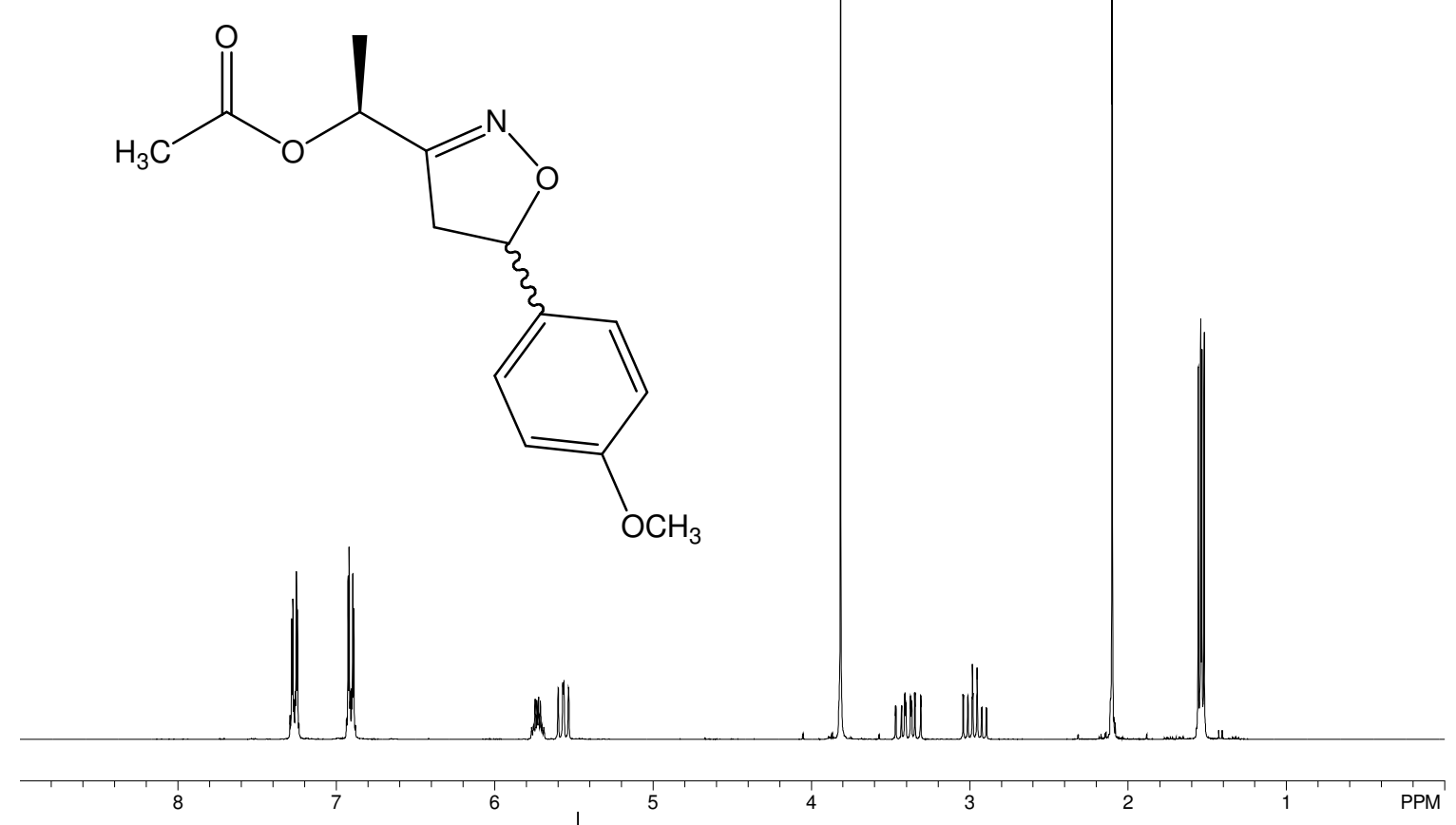


Figure 7. APT spectrum of $\mathbf{1 1 .}$

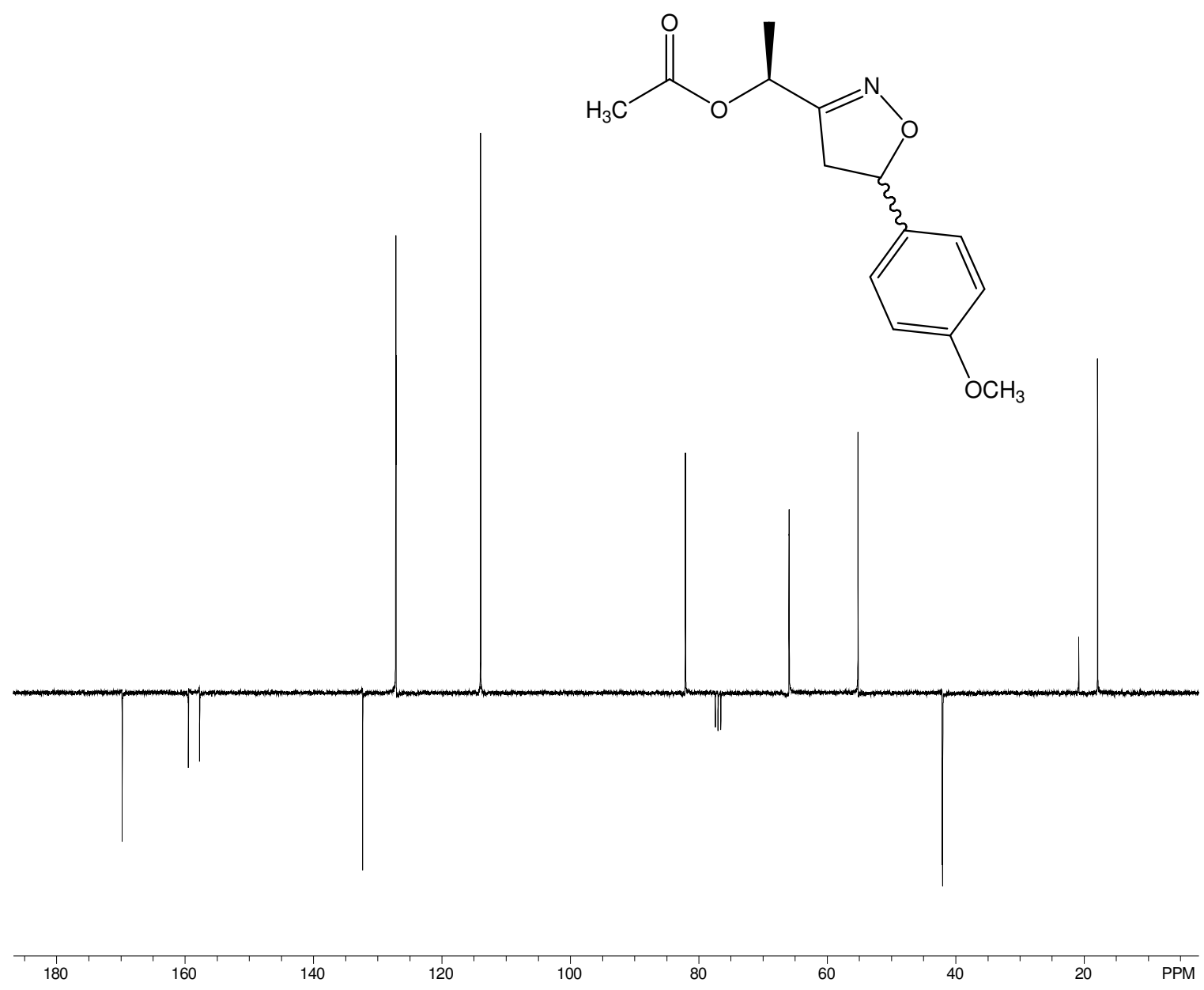


Figure 8. COSY spectrum of 11.

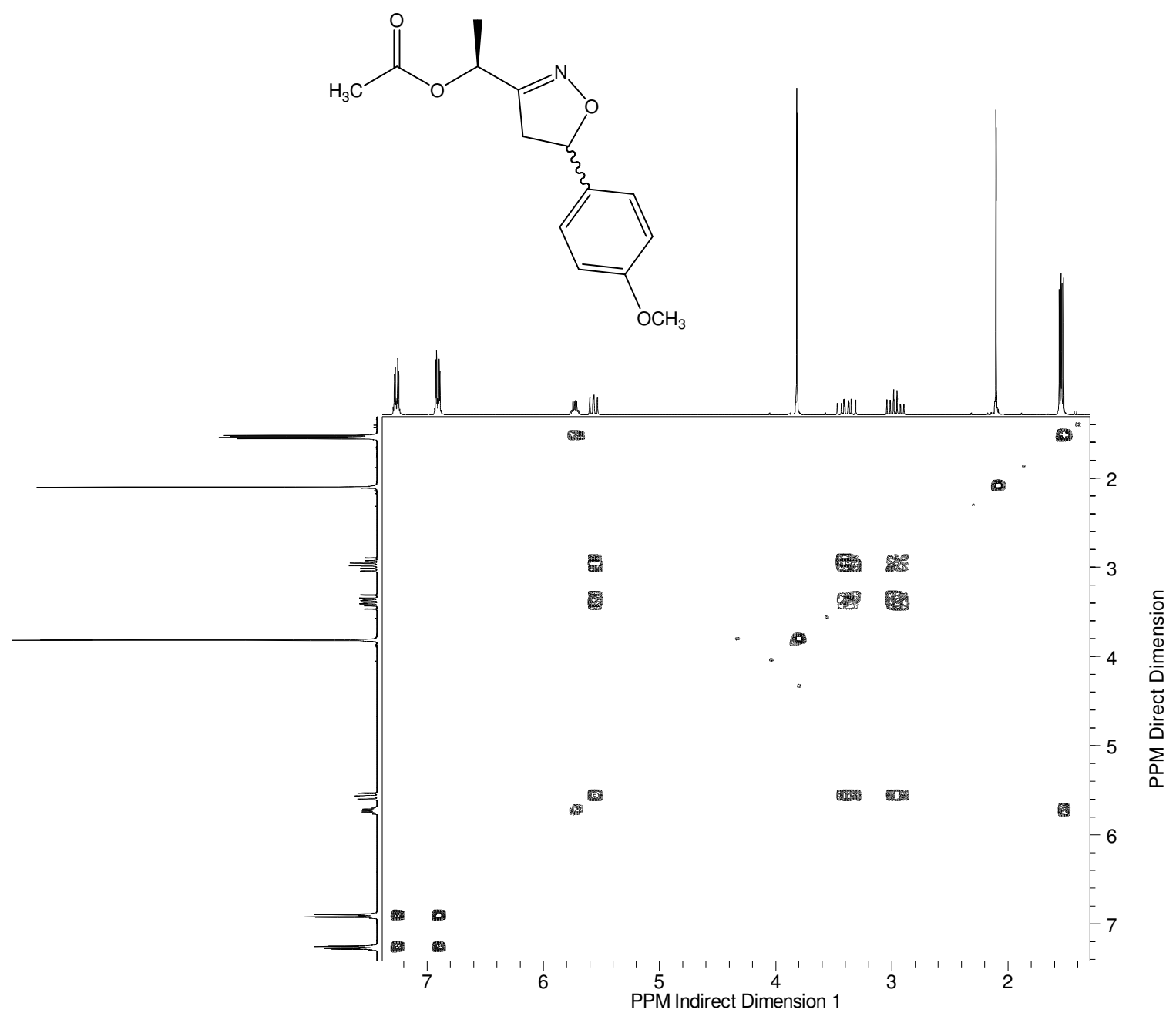


Figure 9. HSQC spectrum of $\mathbf{1 1 .}$

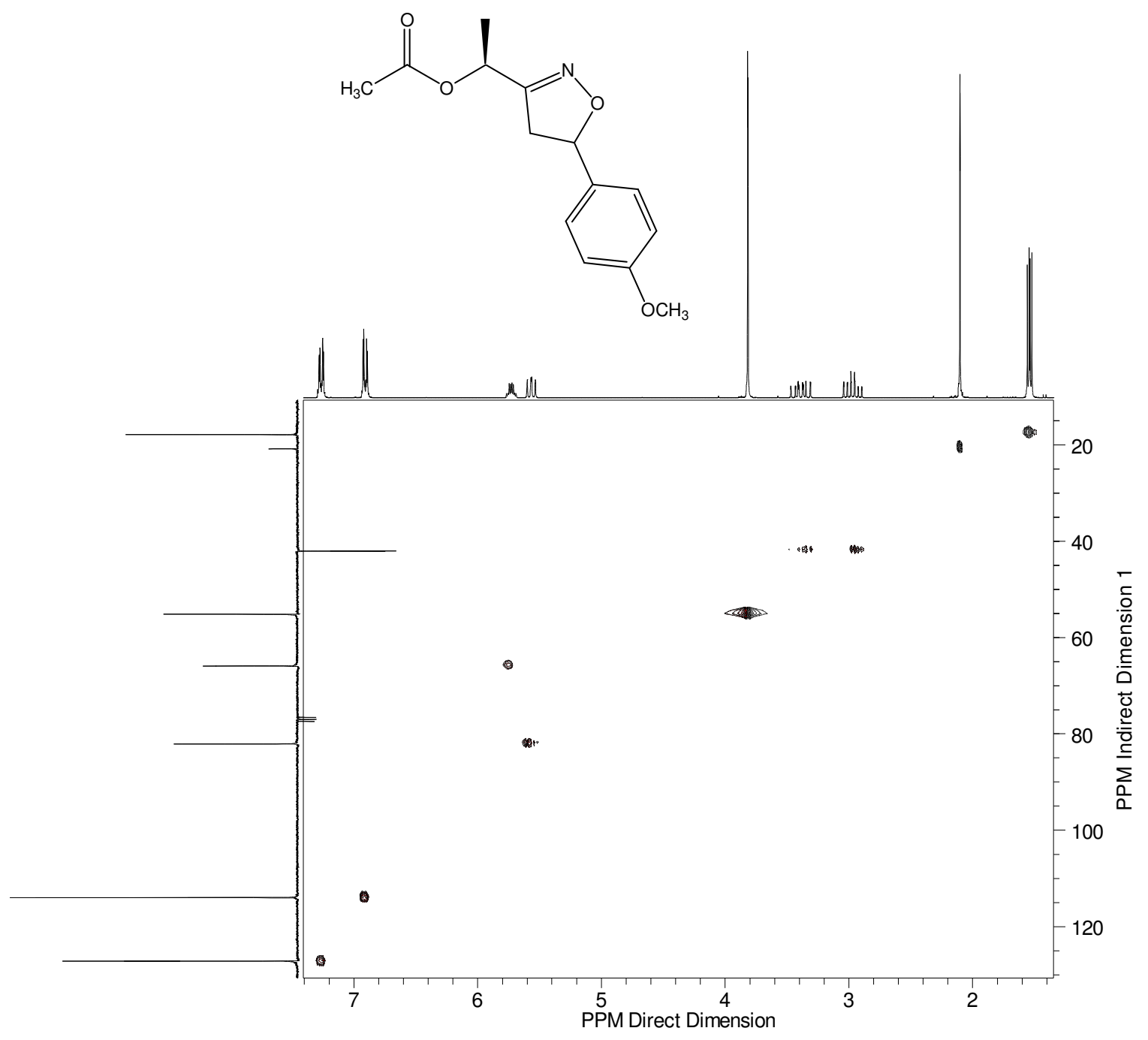


Figure 10. ${ }^{1} \mathrm{H}$ and ${ }^{13} \mathrm{C}\left\{{ }^{1} \mathrm{H}\right\}$ spectra of $\mathbf{1 2}$.
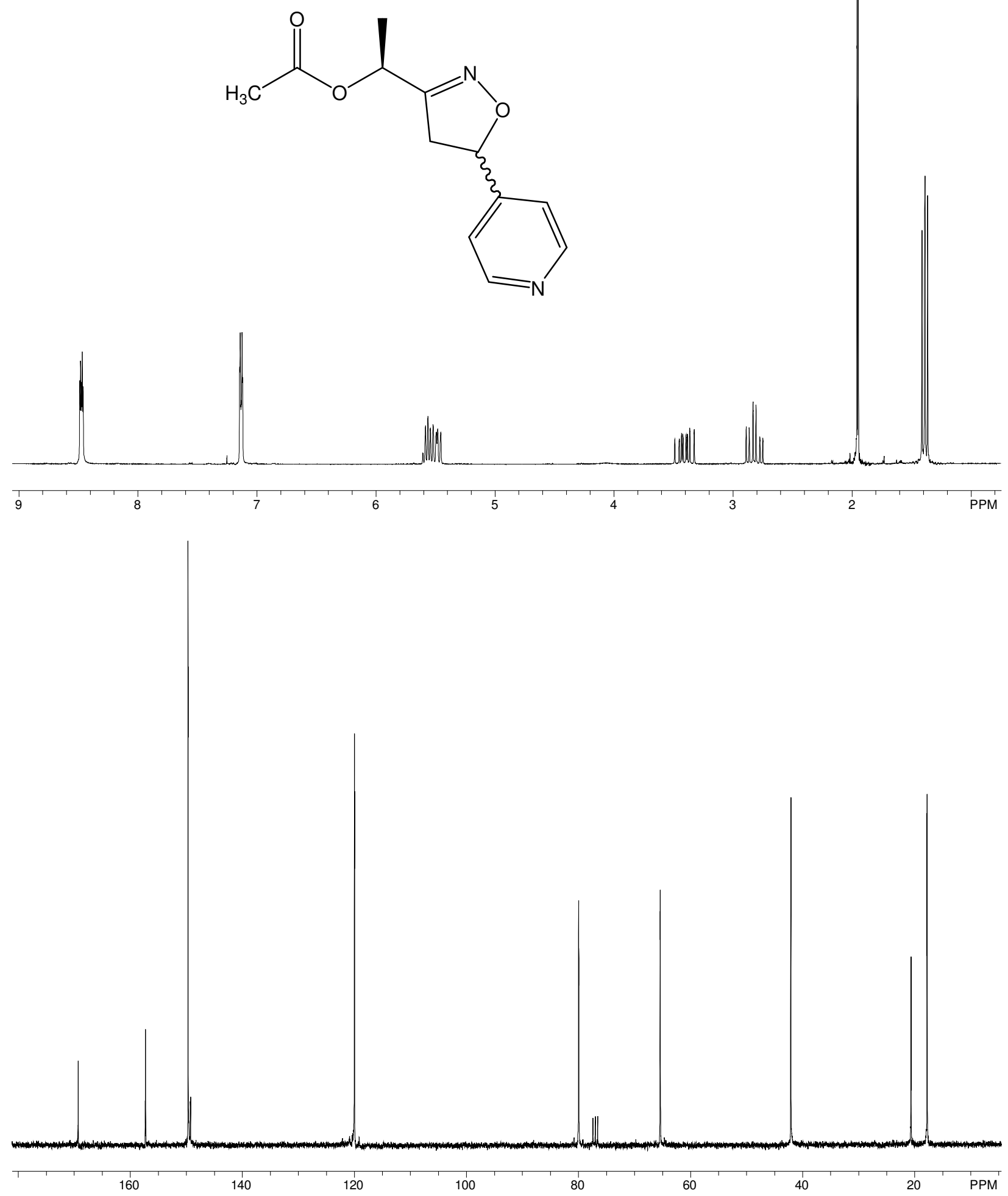
Figure 11. APT spectrum of $\mathbf{1 2}$.

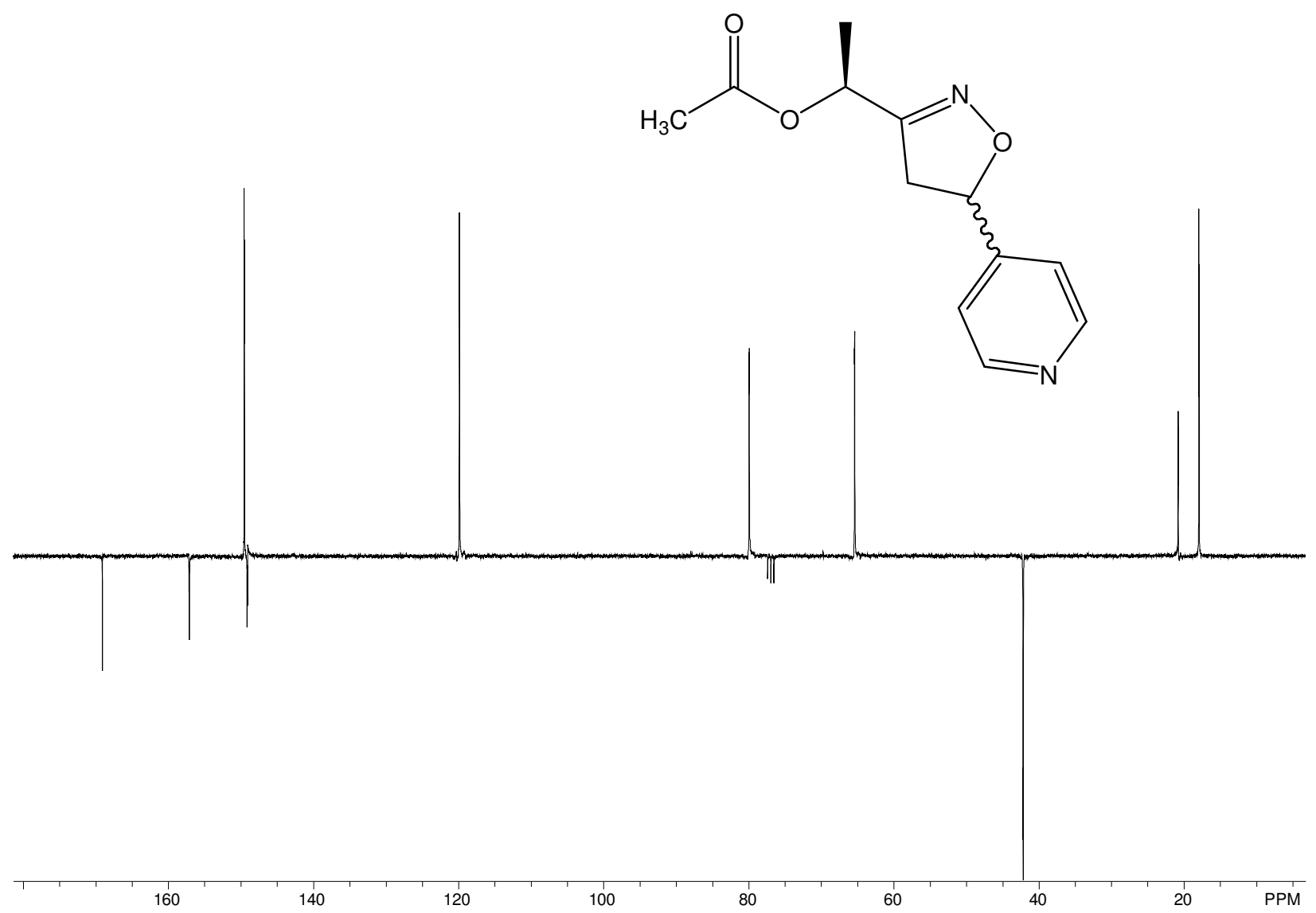


Figure 12. COSY spectrum of 12.

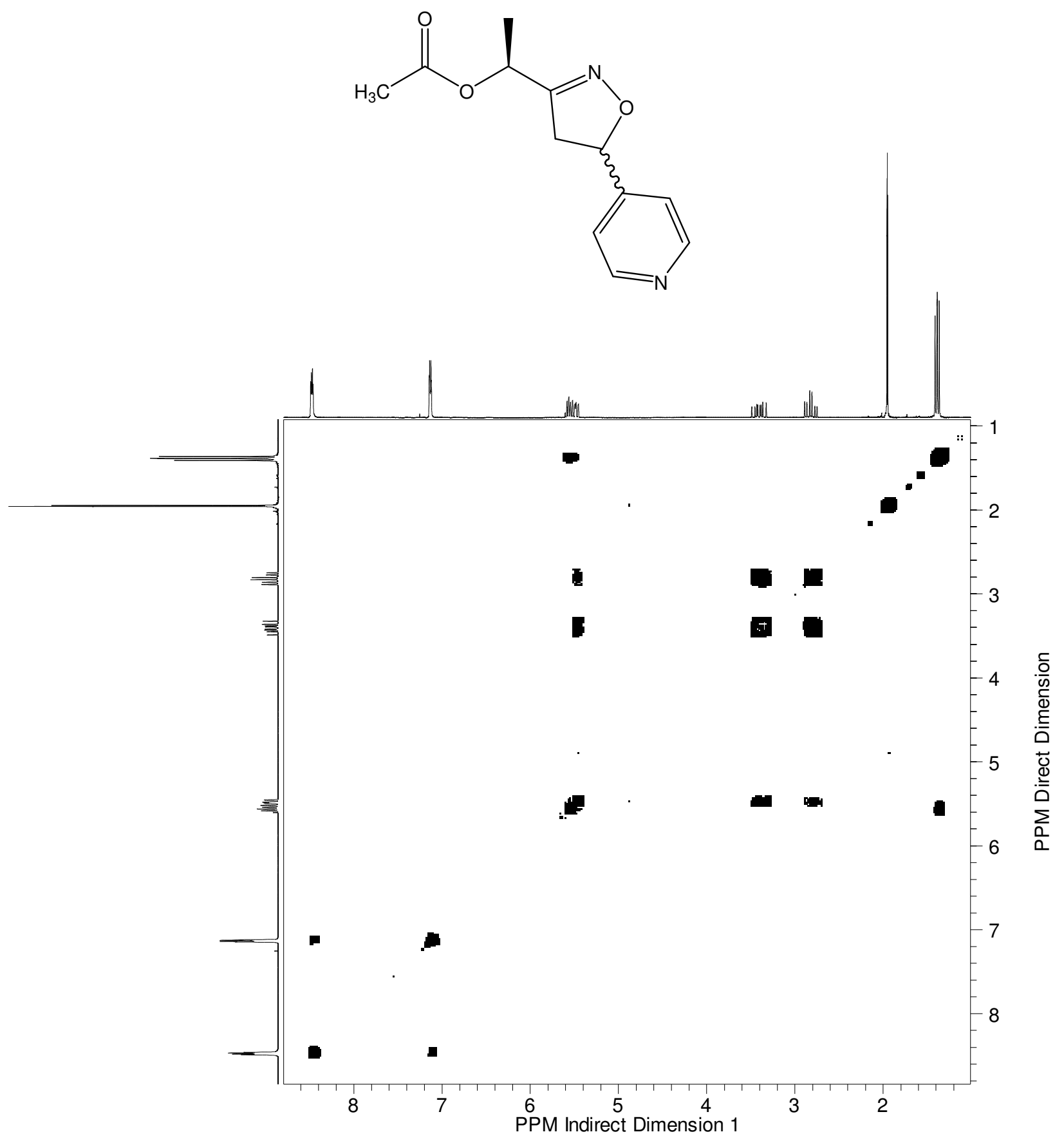


Figure 13. HSQC spectrum of $\mathbf{1 2 .}$

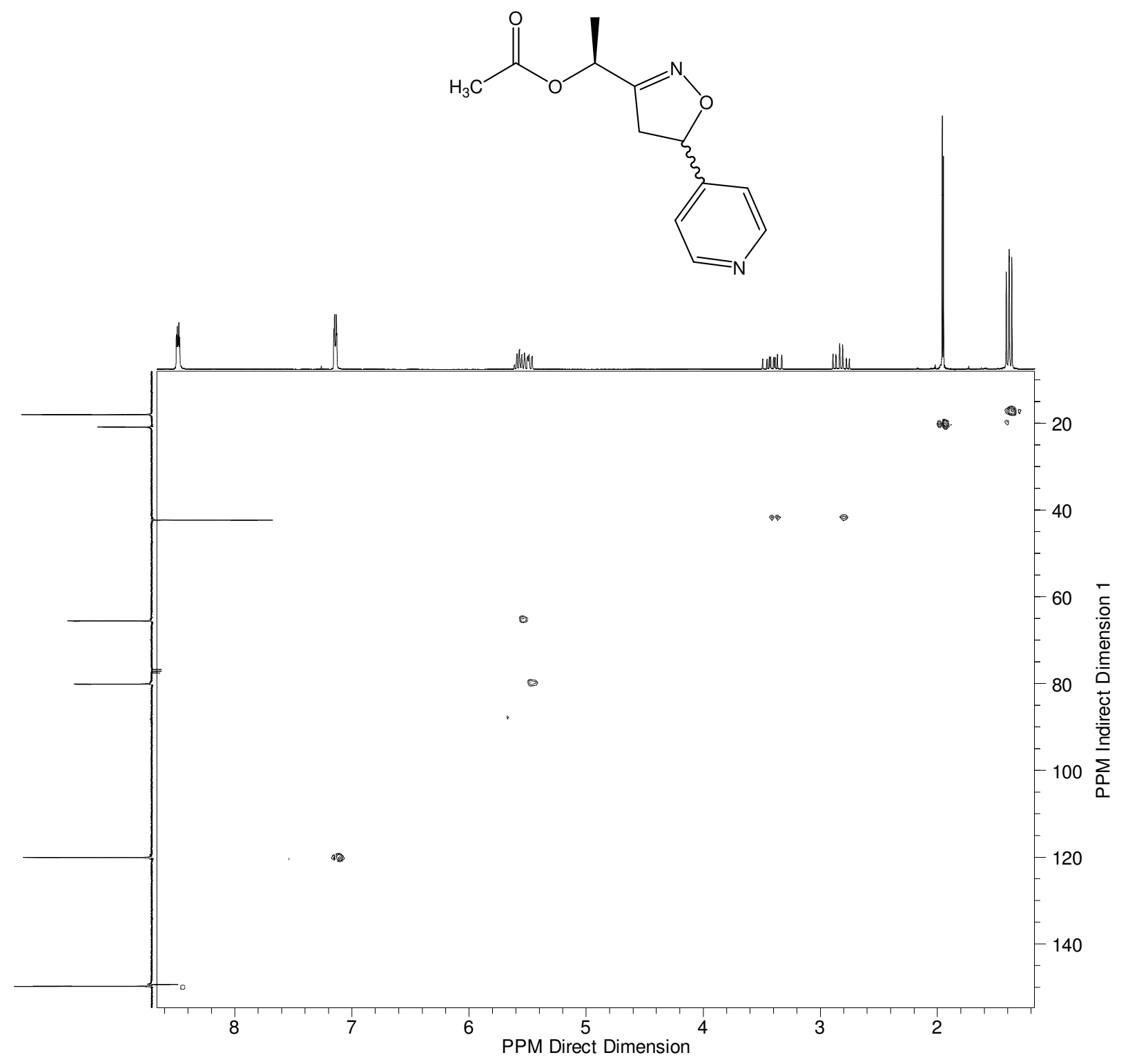


Figure 14. ${ }^{1} \mathrm{H}$ and ${ }^{13} \mathrm{C}\left\{{ }^{1} \mathrm{H}\right\}$ spectra of $R-\mathbf{1 5}$.
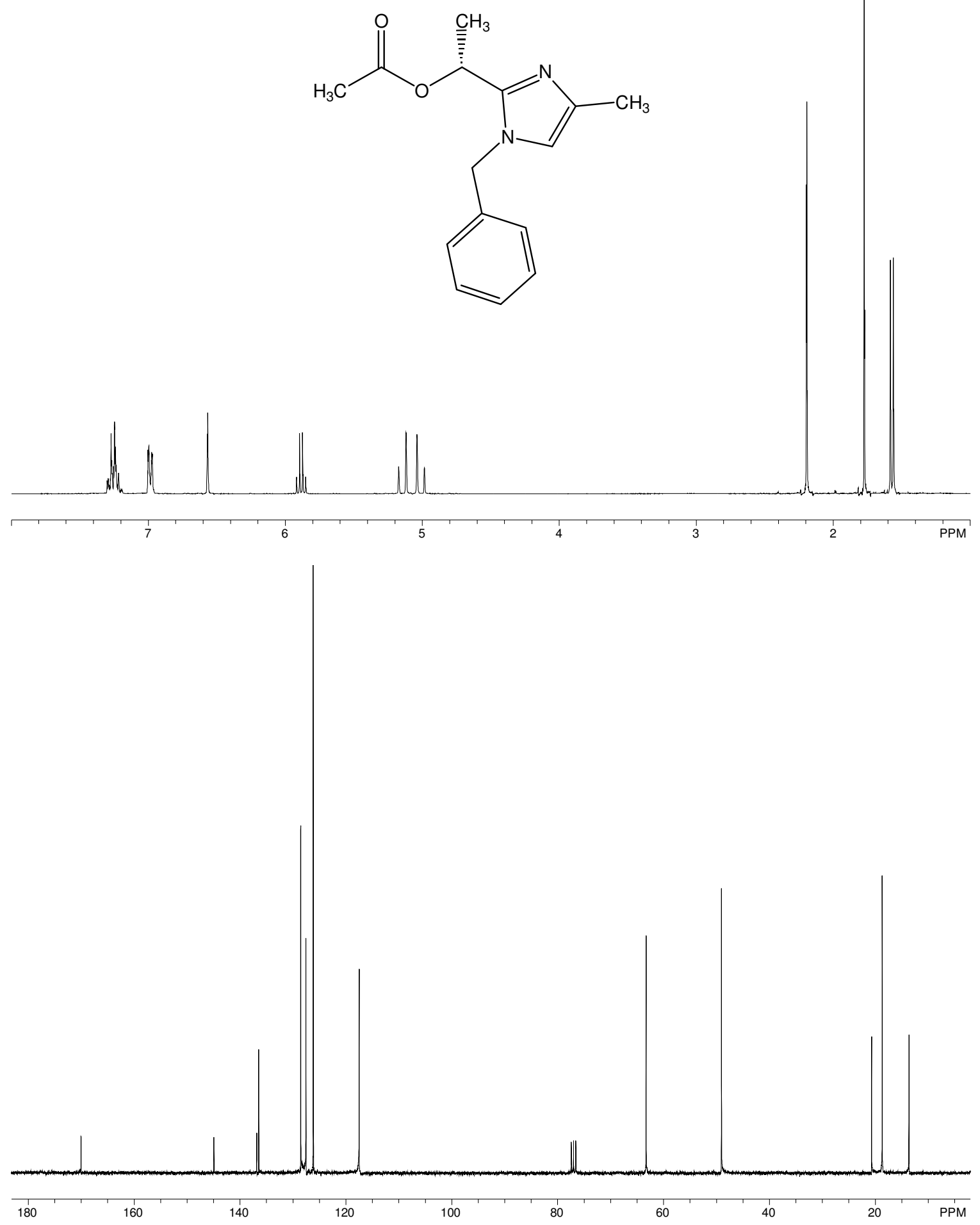
Figure 15. APT spectrum of $R \mathbf{- 1 5}$.

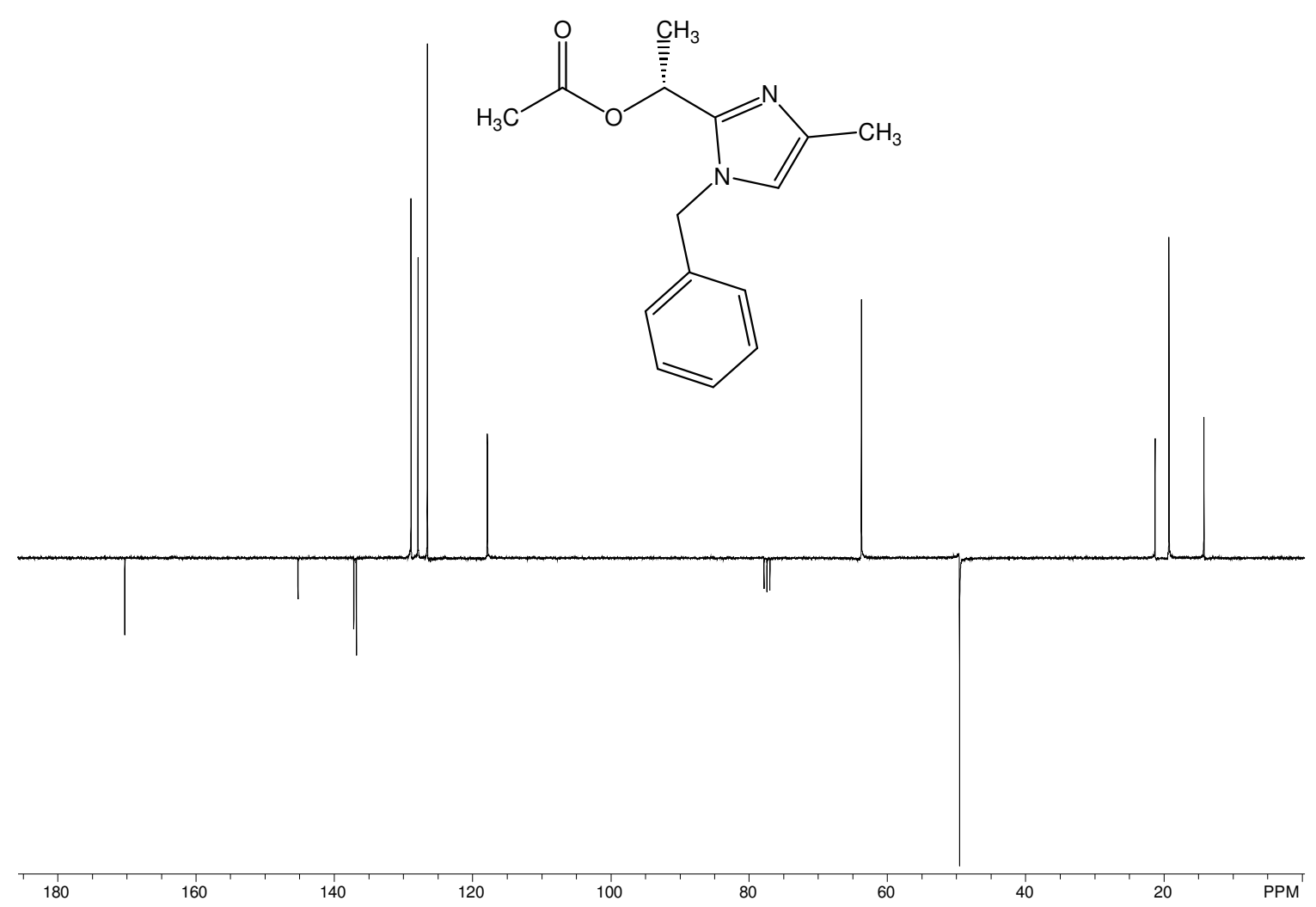


Figure 16. COSY spectrum of $R-\mathbf{1 5}$.

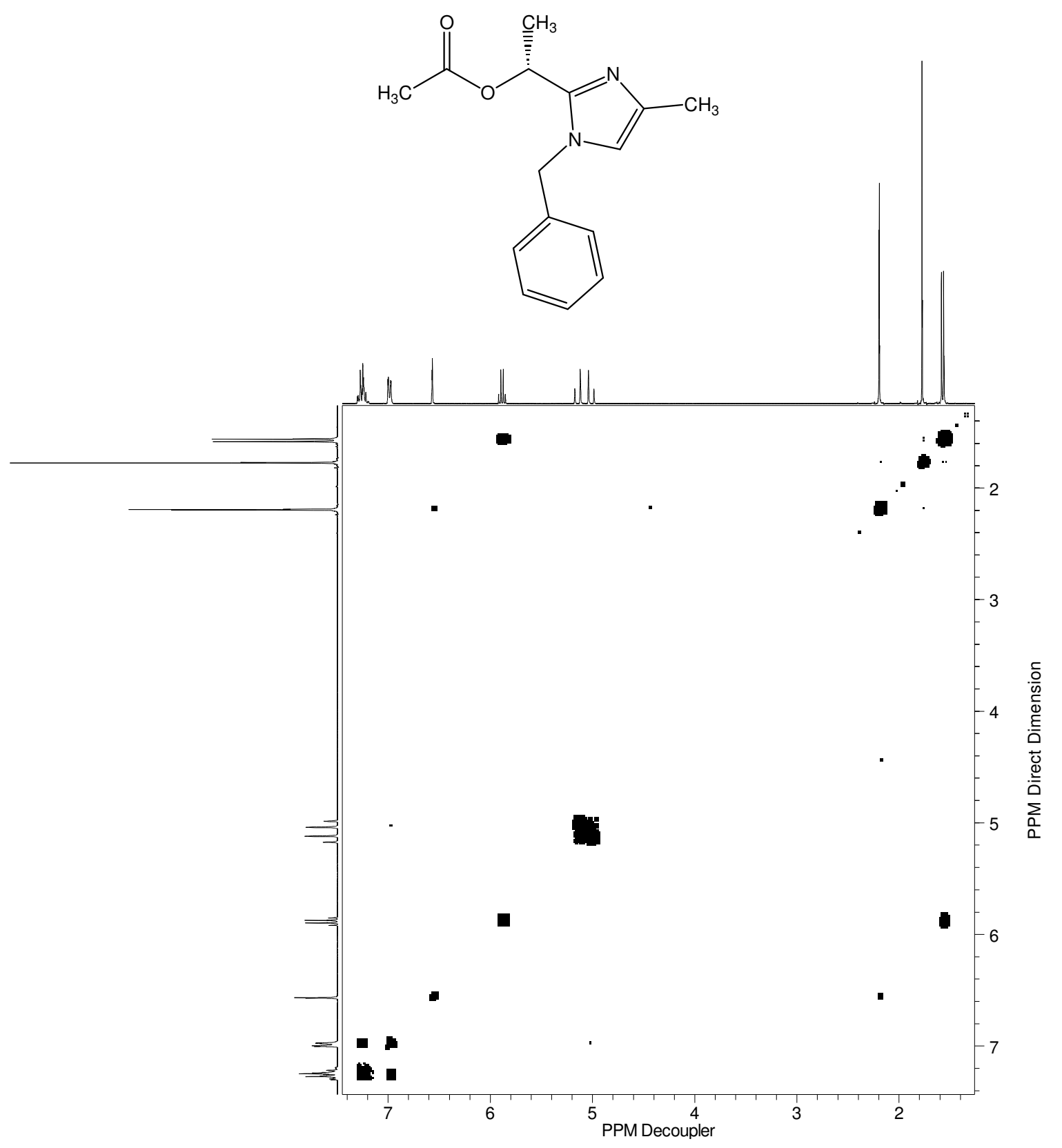


Figure 17. HSQC spectrum of $R-\mathbf{1 5}$.

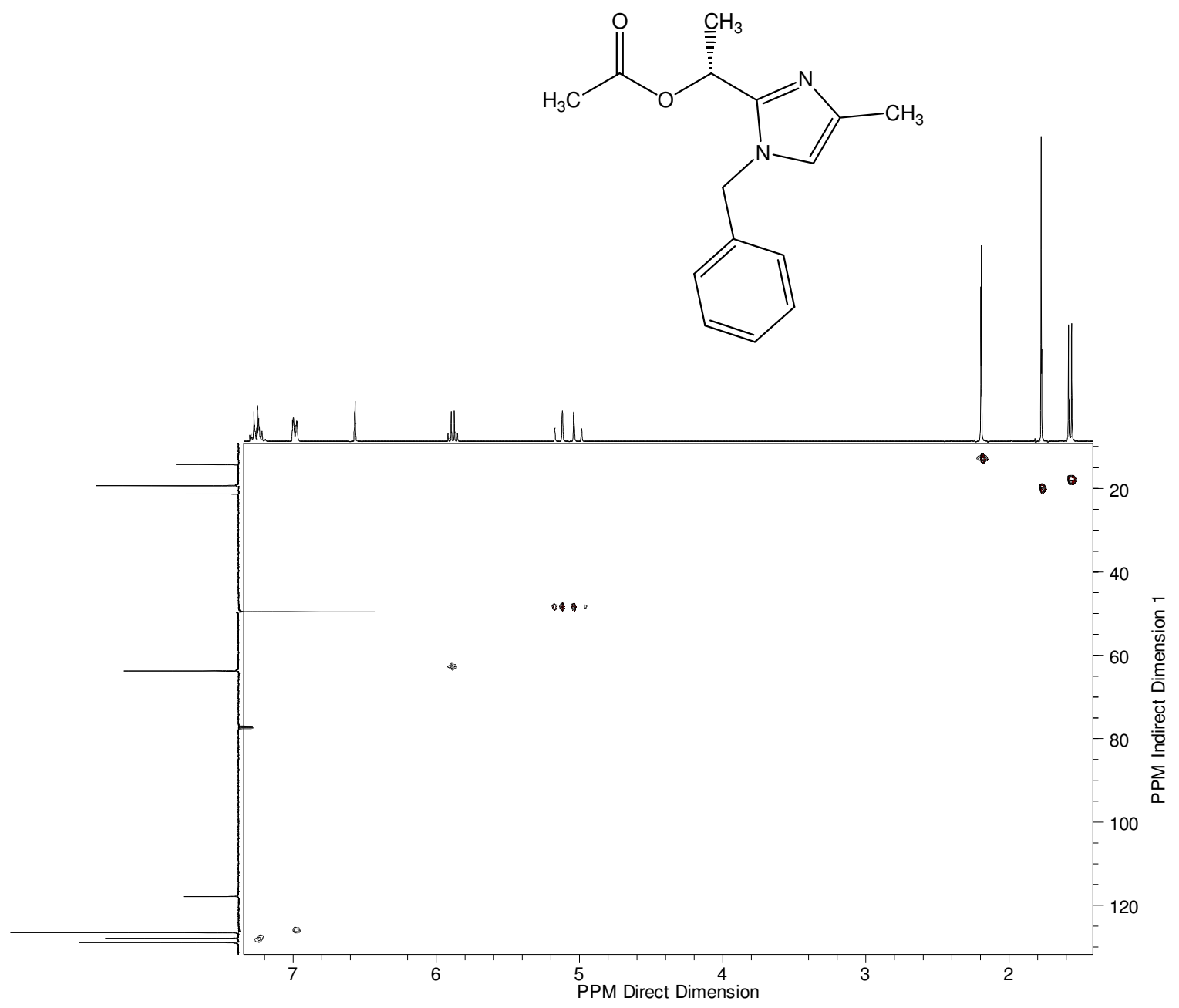




\section{Single Crystal X-ray Analysis Data for $(R)-\mathbf{9}$.}

A white plate-shaped crystal (cut from a larger plate) of dimensions $0.24 \times 0.18 \times 0.11$ mm was immersed in oil, Paratone N, Exxon, and mounted on a thin glass fiber. The crystal was transferred to a Bruker SMART PLATFORM diffractometer equipped with a graphite monochromatic crystal, a MoK $\alpha$ radiation source $(\lambda=0.71073 \AA$ ), a CCD (charge coupled device) area detector which is kept at $4.979 \mathrm{~cm}$ from the crystal. The crystal was bathed in a cold nitrogen stream for the duration of data collection $\left(-100^{\circ} \mathrm{C}\right)$. Three sets of 20 frames each were collected covering three perpendicular sectors of space using the $\omega$ scan method and with a ten second exposure time. Integration of the frames followed by reflection indexing and least squares refinement produced a crystal orientation matrix and a orthorhombic lattice.

All 1381 crystallographic raw data frames were read by program SAINT ${ }^{2}$ and integrated using 3D profiling algorithms. The resulting data were reduced to produce hkl reflections and their intensities and estimated standard deviations. The data were corrected for Lorentz and polarization effects. A total of 4877 reflections were collected representing a range of 4.63 to 5.88 redundancy level and have an $\mathrm{R}_{\text {sym }}$ value range of $7.6 \%$, at the lowest $2 \theta$ shell of reflections, to $7.3 \%$ at the highest $2 \theta$ shell of reflections $\left(55^{\circ}\right)$. Crystal decay correction was applied and was less than $1 \%$. The unit cell parameters were refined by least squares of the setting angles of 4305 reflections.

Absorption corrections were applied by integration based on indexed measured faces. Absorption coefficient was $0.45 \mathrm{~mm}^{-1}$ and minimum and maximum transmissions were 0.9012 and 0.9535 , respectively.

Data preparation was carried out using program $\mathrm{XPREP}^{2}$. The space group was determined to be $\mathrm{P} 2{ }_{1} 2_{1} 2_{1}$ (\# 19) based on systematic absences. XPREP provided the following crystallographic parameters: 1693 unique reflections $\left(\mathrm{R}_{\mathrm{int}}=7.26 \%\right)$ with indices $-7 \leq \mathrm{h} \leq 7$, $13 \leq \mathrm{k} \leq 11,-15 \leq \mathrm{l} \leq 14$.

The structure was solved by direct methods in SHELXTL6. $1^{3}$ from which the positions of all of the non-H atoms were obtained. The structure was refined, also in SHELXTL6.1, using full-matrix least-squares refinement. The non- $\mathrm{H}$ atoms were refined with anisotropic thermal

2 SMART, SAINT and XPREP programs are part of Bruker crystallographic software package for single crystal data collection, reduction and preparation.

3 Sheldrick, G. M. (2000). SHELXTL6.1. Crystallographic software package. Bruker AXS, Inc. Madison, Wisconsin, USA. 
parameters and all of the $\mathrm{H}$ atoms were calculated in idealized positions and refined riding on their parent atoms, except the hydroxyl proton which were obtained from a Difference Fourier map and refined without any constraints. In the final cycle of refinement, 1654 observed reflections with $\mathrm{I}>2 \sigma(\mathrm{I})$ were used to refine 98 parameters and the resulting $\mathrm{R}_{1}$, wR $\mathrm{R}_{2}$ and $\mathrm{S}$ (goodness of fit) were 3.19\%, 7.87\% and 1.084, respectively. A correction for secondary extinction was applied with $\mathrm{x}=0.026(5)$. The maximum and minimum residual electron density peaks in the final Difference Fourier map were 0.256 e. $\AA^{-3}$ and -0.251 e. $\AA^{-3}$, respectively. The correct absolute configuration is reported here as evidenced by the small value of the Flack $\mathrm{x}$ parameter 0.05(6). The refinement was carried out using $F^{2}$ rather than $F$ values. $R_{1}$ is calculated to provide a reference to the conventional $\mathrm{R}$ value but its function is not minimized. Additionally, $w R_{2}$ is the functions that is minimized and not $R_{1}$.

The linear absorption coefficient, atomic scattering factors and anomalous-dispersion corrections were calculated from values from the International Tables for X-ray Crystallography. ${ }^{4}$

\footnotetext{
${ }^{4}$ International Tables for X-ray Crystallography (1974). Vol. IV, p. 55. Birmingham: Kynoch Press. (Present
} distributor, D. Reidel, Dordrecht.). 
Table 1. Crystal data and structure refinement for $(R)-\mathbf{9}$.

Empirical formula

Formula weight

Temperature

Wavelength

Crystal system

Space group

Unit cell dimensions

Volume

$\mathrm{Z}$

Density (calculated)

Absorption coefficient

$\mathrm{F}(000)$

Crystal size

Theta range for data collection

Index ranges

Reflections collected

Independent reflections

Completeness to theta $=27.50^{\circ}$

Absorption correction

Max. and min. transmission

Refinement method

Data / restraints / parameters

Goodness-of-fit on $\mathrm{F}^{2}$

Final $\mathrm{R}$ indices [I $>2 \operatorname{sigma}(\mathrm{I})]$

$\mathrm{R}$ indices (all data)

Absolute structure parameter

Extinction coefficient

Largest diff. peak and hole
$\mathrm{C}_{5} \mathrm{H}_{8} \mathrm{ClNO}_{3}$

165.57

173(2) K

$0.71073 \AA$

Orthorhombic

$\mathrm{P} 2{ }_{1} 2_{1} 2_{1}$

$\mathrm{a}=6.1304(6) \AA \quad \alpha=90^{\circ}$.

$\mathrm{b}=10.4292(10) \AA \quad \beta=90^{\circ}$.

$\mathrm{c}=11.9236(11) \AA \quad \gamma=90^{\circ}$.

762.34(13) $\AA^{3}$

4

$1.443 \mathrm{Mg} / \mathrm{m}^{3}$

$0.450 \mathrm{~mm}^{-1}$

344

$0.24 \times 0.18 \times 0.11 \mathrm{~mm}^{3}$

2.59 to $27.50^{\circ}$.

$-7 \leq \mathrm{h} \leq 7,-13 \leq \mathrm{k} \leq 11,-15 \leq \mathrm{l} \leq 14$

4877

$1693[\mathrm{R}(\mathrm{int})=0.0726]$

$98.6 \%$

Integration

0.9535 and 0.9012

Full-matrix least-squares on $\mathrm{F}^{2}$

1693 / 0 / 98

1.084

$\mathrm{R} 1=0.0319, \mathrm{wR} 2=0.0787$ [1654]

$\mathrm{R} 1=0.0325, \mathrm{wR} 2=0.0793$

$0.05(6)$

$0.026(5)$

0.256 and -0.251 e. $\AA^{-3}$

$\mathrm{R} 1=\sum\left(|| \mathrm{F}_{\mathrm{O}}|-| \mathrm{F}_{\mathrm{C}} \|\right) / \sum\left|\mathrm{F}_{\mathrm{O}}\right|$

$w R 2=\left[\sum\left[w\left(F_{\mathrm{o}}{ }^{2}-\mathrm{F}_{\mathrm{c}}{ }^{2}\right)^{2}\right] / \Sigma\left[\mathrm{w}\left(\mathrm{F}_{\mathrm{o}}{ }^{2}\right)^{2}\right]\right]^{1 / 2}$

$\mathrm{S}=\left[\sum\left[\mathrm{w}\left(\mathrm{F}_{\mathrm{O}}^{2}-\mathrm{F}_{\mathrm{C}}^{2}\right)^{2}\right] /(\mathrm{n}-\mathrm{p})\right]^{1 / 2}$

$\mathrm{w}=1 /\left[\sigma^{2}\left(\mathrm{~F}_{\mathrm{o}}{ }^{2}\right)+(\mathrm{m} * \mathrm{p})^{2}+\mathrm{n} * \mathrm{p}\right], \mathrm{p}=\left[\max \left(\mathrm{F}_{\mathrm{o}}{ }^{2}, 0\right)+2 * \mathrm{~F}_{\mathrm{c}}{ }^{2}\right] / 3, \mathrm{~m} \& \mathrm{n}$ are constants. 
Table 2. Atomic coordinates ( $\left.\times 10^{4}\right)$ and equivalent isotropic displacement parameters $\left(\AA^{2} \times 10^{3}\right)$ for $(R)-9 . \mathrm{U}(\mathrm{eq})$ is defined as one third of the trace of the orthogonalized $\mathrm{U}^{\mathrm{ij}}$ tensor.

\begin{tabular}{lrrrr}
\hline & $\mathrm{x}$ & $\mathrm{y}$ & $\mathrm{z}$ & $\mathrm{U}(\mathrm{eq})$ \\
\hline $\mathrm{Cl}$ & $730(1)$ & $847(1)$ & $5989(1)$ & $38(1)$ \\
$\mathrm{O} 1$ & $-1897(2)$ & $2582(1)$ & $7154(1)$ & $36(1)$ \\
$\mathrm{O} 2$ & $-5239(2)$ & $-1157(1)$ & $6503(1)$ & $31(1)$ \\
$\mathrm{O} 3$ & $-2648(2)$ & $-1079(1)$ & $5181(1)$ & $27(1)$ \\
$\mathrm{N} 1$ & $-3157(2)$ & $1862(1)$ & $6415(1)$ & $28(1)$ \\
$\mathrm{C} 1$ & $-2913(3)$ & $-2994(1)$ & $6212(1)$ & $32(1)$ \\
$\mathrm{C} 2$ & $-2447(3)$ & $547(2)$ & $3782(1)$ & $33(1)$ \\
$\mathrm{C} 3$ & $-3180(3)$ & $263(1)$ & $4970(1)$ & $25(1)$ \\
$\mathrm{C} 4$ & $-3756(2)$ & $-1670(1)$ & $6004(1)$ & $24(1)$ \\
$\mathrm{C} 5$ & $-2059(2)$ & $1073(1)$ & $5834(1)$ & $24(1)$ \\
& & & & \\
\hline
\end{tabular}

Table 3. Bond lengths $[\AA]$ and angles $\left[{ }^{\circ}\right]$ for $(R)-\mathbf{9}$.

\begin{tabular}{ll|ll}
\hline Cl-C5 & $1.736(2)$ & $\mathrm{C} 2-\mathrm{H} 2 \mathrm{~B}$ & 0.9800 \\
O1-N1 & $1.391(2)$ & $\mathrm{C} 2-\mathrm{H} 2 \mathrm{C}$ & 0.9800 \\
O1-H1 & $0.87(3)$ & $\mathrm{C} 3-\mathrm{C} 5$ & $1.500(2)$ \\
O2-C4 & $1.212(2)$ & $\mathrm{C} 3-\mathrm{H} 3 \mathrm{~A}$ & 1.0000 \\
O3-C4 & $1.343(2)$ & & \\
O3-C3 & $1.459(2)$ & N1-O1-H1 & $102(2)$ \\
N1-C5 & $1.269(2)$ & C4-O3-C3 & $116.9(1)$ \\
C1-C4 & $1.495(2)$ & C5-N1-O1 & $113.6(1)$ \\
C1-H1A & 0.9800 & C4-C1-H1A & 109.5 \\
C1-H1B & 0.9800 & C4-C1-H1B & 109.5 \\
C1-H1C & 0.9800 & H1A-C1-H1B & 109.5 \\
C2-C3 & $1.515(2)$ & C4-C1-H1C & 109.5 \\
C2-H2A & 0.9800 & H1A-C1-H1C & 109.5
\end{tabular}




\begin{tabular}{ll|ll} 
H1B-C1-H1C & 109.5 & O3-C3-H3A & 109.5 \\
C3-C2-H2A & 109.5 & C5-C3-H3A & 109.5 \\
C3-C2-H2B & 109.5 & C2-C3-H3A & 109.5 \\
H2A-C2-H2B & 109.5 & O2-C4-O3 & $122.4(1)$ \\
C3-C2-H2C & 109.5 & O2-C4-C1 & $125.9(1)$ \\
H2A-C2-H2C & 109.5 & O3-C4-C1 & $111.8(1)$ \\
H2B-C2-H2C & 109.5 & N1-C5-C3 & $119.8(1)$ \\
O3-C3-C5 & $108.7(1)$ & N1-C5-Cl & $123.5(1)$ \\
O3-C3-C2 & $106.4(10)$ & & $116.6(1)$ \\
C5-C3-C2 & $113.3(1)$ &
\end{tabular}

Table 4. Anisotropic displacement parameters $\left(\AA^{2} \times 10^{3}\right)$ for $(R)-9$. The anisotropic displacement factor exponent takes the form: $-2 \pi^{2}\left[h^{2} a^{* 2} U^{11}+\ldots+2 h k a^{*} b^{*} U^{12}\right]$

\begin{tabular}{lllllll}
\hline & $\mathrm{U}^{11}$ & $\mathrm{U}^{22}$ & $\mathrm{U}^{33}$ & $\mathrm{U}^{23}$ & $\mathrm{U}^{13}$ & $\mathrm{U}^{12}$ \\
\hline $\mathrm{Cl}$ & $23(1)$ & $46(1)$ & $47(1)$ & $-16(1)$ & $1(1)$ & $6(1)$ \\
$\mathrm{O} 1$ & $32(1)$ & $38(1)$ & $38(1)$ & $-15(1)$ & $5(1)$ & $1(1)$ \\
$\mathrm{O} 2$ & $28(1)$ & $35(1)$ & $30(1)$ & $5(1)$ & $6(1)$ & $0(1)$ \\
$\mathrm{O} 3$ & $29(1)$ & $23(1)$ & $29(1)$ & $1(1)$ & $7(1)$ & $0(1)$ \\
$\mathrm{N} 1$ & $29(1)$ & $26(1)$ & $29(1)$ & $-3(1)$ & $5(1)$ & $2(1)$ \\
$\mathrm{C} 1$ & $35(1)$ & $27(1)$ & $36(1)$ & $3(1)$ & $-2(1)$ & $-2(1)$ \\
$\mathrm{C} 2$ & $44(1)$ & $32(1)$ & $24(1)$ & $3(1)$ & $5(1)$ & $4(1)$ \\
$\mathrm{C} 3$ & $26(1)$ & $24(1)$ & $26(1)$ & $2(1)$ & $4(1)$ & $2(1)$ \\
$\mathrm{C} 4$ & $23(1)$ & $28(1)$ & $21(1)$ & $-1(1)$ & $-2(1)$ & $-6(1)$ \\
$\mathrm{C} 5$ & $22(1)$ & $26(1)$ & $25(1)$ & $2(1)$ & $5(1)$ & $2(1)$ \\
& & & & & & \\
\hline
\end{tabular}


Table 5. Hydrogen coordinates ( $\left.\times 10^{4}\right)$ and isotropic displacement parameters $\left(\AA^{2} \times 10^{3}\right)$

For $(R)-9$.

\begin{tabular}{lcccc}
\hline & $x$ & $y$ & $z$ & $U(e q)$ \\
\hline H1 & & & & \\
H1A & $-2890(40)$ & $2990(30)$ & $7540(20)$ & $63(7)$ \\
H1B & -3757 & -3395 & 6816 & 49 \\
H1C & -1373 & -2950 & 6431 & 49 \\
H2A & -3056 & -3506 & 5527 & 49 \\
H2B & -868 & 418 & 3724 & 49 \\
H2C & -2804 & 1437 & 3594 & 49 \\
H3A & -3196 & -31 & 3261 & 49 \\
& -4794 & 386 & 5028 & 30
\end{tabular}

Table 6. Hydrogen bonds for $(R)-9$ [ $\AA^{\circ}$ and $\left.^{\circ}\right]$.

\begin{tabular}{lllll}
\hline D-H...A & $\mathrm{d}(\mathrm{D}-\mathrm{H})$ & $\mathrm{d}(\mathrm{H} \ldots \mathrm{A})$ & $\mathrm{d}(\mathrm{D} \ldots \mathrm{A})$ & $<(\mathrm{DHA})$ \\
\hline $\mathrm{O} 1-\mathrm{H} 1 \ldots \mathrm{O} 2 \# 1$ & $0.87(3)$ & $1.85(3)$ & $2.7162(15)$ & $173(2)$ \\
\hline
\end{tabular}

Symmetry transformations used to generate equivalent atoms:

$\# 1-x-1, y+1 / 2,-z+3 / 2$ 